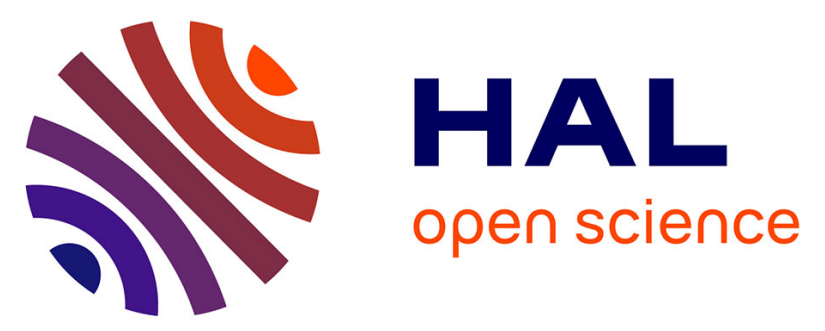

\title{
A porous puckered V2O5 polymorph as new high performance cathode material for aqueous rechargeable zinc batteries
}

Daureen Batyrbekuly, Barbara Laï, Jean Pierre Pereira-Ramos, Zhumabay Bakenov, Rita Baddour-Hadjean

\section{To cite this version:}

Daureen Batyrbekuly, Barbara Laïk, Jean Pierre Pereira-Ramos, Zhumabay Bakenov, Rita BaddourHadjean. A porous puckered V2O5 polymorph as new high performance cathode material for aqueous rechargeable zinc batteries. Journal of Energy Chemistry, 2021, 61, pp.459-468. 10.1016/j.jechem.2021.01.042 . hal-03139633

\section{HAL Id: hal-03139633 https://hal.science/hal-03139633}

Submitted on 7 Jul 2021

HAL is a multi-disciplinary open access archive for the deposit and dissemination of scientific research documents, whether they are published or not. The documents may come from teaching and research institutions in France or abroad, or from public or private research centers.
L'archive ouverte pluridisciplinaire HAL, est destinée au dépôt et à la diffusion de documents scientifiques de niveau recherche, publiés ou non, émanant des établissements d'enseignement et de recherche français ou étrangers, des laboratoires publics ou privés. 


\title{
A porous puckered $\mathrm{V}_{2} \mathrm{O}_{5}$ polymorph as new high performance cathode material for aqueous rechargeable zinc batteries
}

Dauren Batyrbekulya,b, Barbara Laïk ${ }^{\mathrm{a}}$, Jean-Pierre Pereira-Ramos ${ }^{\mathrm{a}}$, Zhumabay

Bakenov $^{\mathrm{b}}$, Rita Baddour-Hadjean ${ }^{\mathrm{a},}$,

${ }^{a}$ Institut de Chimie et des Matériaux Paris Est (ICMPE), UMR 7182 CNRS et

Université Paris Est Créteil, 2 rue Henri Dunant, 94320 Thiais, France

${ }^{\mathrm{b}}$ School of Engineering, National Laboratory Astana, Nazarbayev University, 53

Kabanbay Batyr Avenue, Astana 010000, Kazakhstan

*Corresponding author.

E-mail address: baddour@icmpe.cnrs.fr (R. Baddour-Hadjean)

\begin{abstract}
Aqueous rechargeable zinc batteries are getting increasing attention for large-scale energy storage owing to their advantages in terms of cost, environmental friendliness and safety. Here, the layered puckered $\gamma^{\prime}-\mathrm{V}_{2} \mathrm{O}_{5}$ polymorph with a porous morphology is firstly introduced as cathode for an aqueous zinc battery system in a binary $\mathrm{Zn}^{2+} / \mathrm{Li}^{+}$ electrolyte. The $\mathrm{Zn} \| \gamma^{\prime}-\mathrm{V}_{2} \mathrm{O}_{5}$ cell delivers high capacities of 240 and $190 \mathrm{mAh} \mathrm{g}^{-1}$ at current densities of 29 and $147 \mathrm{~mA} \mathrm{~g}^{-1}$, respectively, and remarkable cycling stability in the $1.6 \mathrm{~V}-0.7 \mathrm{~V}$ voltage window (97\% retention after 100 cycles at $0.15 \mathrm{~A} \mathrm{~g} \mathrm{~g}^{-1}$ ). The detailed structural evolution during first discharge-charge and subsequent cycling is investigated using X-ray diffraction and Raman spectroscopy. We demonstrate a reaction mechanism based on a selective $\mathrm{Li}$ insertion in the $1.6 \mathrm{~V}-1 \mathrm{~V}$ voltage range. It involves a reversible exchange of $0.8 \mathrm{Li}^{+}$in $\gamma^{\prime}-\mathrm{V}_{2} \mathrm{O}_{5}$ and the same structural response as the one reported in lithiated organic electrolyte. However, in the extended $1.6 \mathrm{~V}$ $0.7 \mathrm{~V}$ voltage range, this work puts forward a concomitant and gradual phase transformation from $\gamma^{\prime}-\mathrm{V}_{2} \mathrm{O}_{5}$ to zinc pyrovanadate $\mathrm{Zn}_{3} \mathrm{~V}_{2} \mathrm{O}_{7}(\mathrm{OH})_{2} .2 \mathrm{H}_{2} \mathrm{O}(\mathrm{ZVO})$ during
\end{abstract}


cycling. Such mechanism involving the in-situ formation of ZVO, known as an efficient $\mathrm{Zn}$ and $\mathrm{Li}$ intercalation material, explains the high electrochemical performance here reported for the $\mathrm{Zn} \| \gamma^{\prime}-\mathrm{V}_{2} \mathrm{O}_{5}$ cell. This work highlights the peculiar layered-puckered $\gamma^{\prime}-\mathrm{V}_{2} \mathrm{O}_{5}$ polymorph outperforms the conventional $\alpha-\mathrm{V}_{2} \mathrm{O}_{5}$ with a huge improvement of capacity of $240 \mathrm{mAh} \mathrm{g}^{-1}$ vs $80 \mathrm{mAh} \mathrm{g}^{-1}$ in the same electrolyte and voltage window.

Keywords: Vanadium pentoxide, $\gamma^{\prime}-\mathrm{V}_{2} \mathrm{O}_{5}$, Cathode, Aqueous zinc battery, High performance, Layered structure, Energy storage, Renewable energy

\section{Introduction}

Lithium ion batteries (LIBs) are known to provide the best option in terms of energy density and technical maturity to store renewable energy. However, LIBs large-scale energy storage systems have great limitations such as high cost and insufficient safety. In search of alternative batteries, aqueous rechargeable Zn-based batteries (ARZB) are attractive due to their low cost, safety and moderate toxicity. In addition, the high conductivity of the aqueous electrolyte made of $\mathrm{Zn}$ salts (e.g. $1 \mathrm{M}-3 \mathrm{M} \mathrm{ZnSO} 4)$ allows a substantial gain on rate performance. While traditional alkaline electrolytes induce dendrite formation and byproducts, recent works have demonstrated the use of mild acidic electrolytes $(\mathrm{pH} \approx 4)$ significantly improves the stability of metallic $\mathrm{Zn}$ anode [1-3].

Finding suitable cathode materials for ARZBs with high capacity, high operating voltage and long cycle life is actually a great challenge. Previous explorations of cathode materials mostly concern three main groups [4-6]: Prussian blue and analogues, manganese oxides and vanadium-based compounds that have been extensively investigated owing to the richness of layered structures in that family combined to the multiple oxidation states of vanadium [1,7-27]. Fast rate capability 
and good capacity retention of $80-95 \%$ over a few hundred cycles with specific capacities mostly in the range 100-300 $\mathrm{mAh} \mathrm{g}^{-1}$ have been reported for hydrated Vbased compounds such as $\mathrm{Zn}_{0.25} \mathrm{~V}_{2} \mathrm{O}_{5} . \mathrm{nH}_{2} \mathrm{O}$ [1], $\mathrm{V}_{2} \mathrm{O}_{5} . \mathrm{nH}_{2} \mathrm{O} / \mathrm{RGO}$ [7], $\mathrm{V}_{2} \mathrm{O}_{5}$ xerogel

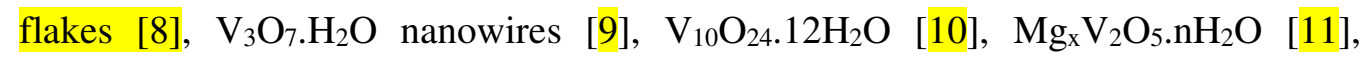
$\mathrm{K}_{2} \mathrm{~V}_{6} \mathrm{O}_{16} \cdot 2.7 \mathrm{H}_{2} \mathrm{O} \quad[12], \quad \mathrm{Ca}_{0.25} \mathrm{~V}_{2} \mathrm{O}_{5} \cdot \mathrm{nH}_{2} \mathrm{O} \quad[13], \quad \mathrm{Na}_{2} \mathrm{~V}_{6} \mathrm{O}_{16} .3 \mathrm{H}_{2} \mathrm{O} \quad$ [14], $\mathrm{Fe}_{5} \mathrm{~V}_{15} \mathrm{O}_{39}(\mathrm{OH}) .9 .9 \mathrm{H}_{2} \mathrm{O}$ nanosheets [15], $\mathrm{Zn}_{3} \mathrm{~V}_{2} \mathrm{O}_{7}(\mathrm{OH})_{2} .2 \mathrm{H}_{2} \mathrm{O}$ [16] and hydrated porous $\delta$ - $\mathrm{Ni}_{0.25} \mathrm{~V}_{2} \mathrm{O}_{5} . \mathrm{nH}_{2} \mathrm{O}$ nanoribbons [17]. Anhydrous vanadium-based phases have also been investigated like $\mathrm{VO}_{2}$ [18], $\mathrm{Zn}_{2} \mathrm{~V}_{2} \mathrm{O}_{7}$ [19], $\mathrm{NH}_{4} \mathrm{~V}_{4} \mathrm{O}_{10}$ [20], $\mathrm{KV}_{3} \mathrm{O}_{8}, \mathrm{~K}_{2} \mathrm{~V}_{8} \mathrm{O}_{21}$ [21] and $\mathrm{LiV}_{3} \mathrm{O}_{8}$ [22].

In contrast to the abundant literature devoted to the vanadium oxide derivatives, very few works concern the conventional anhydrous $\alpha-\mathrm{V}_{2} \mathrm{O}_{5}$ oxide. The reported papers [23-29] focus on the wide operating voltage windows $1.6 \mathrm{~V}-0.5 \mathrm{~V}, 1.5 \mathrm{~V}-0.3$ $\mathrm{V}$ or $1.4 \mathrm{~V}-0.4 \mathrm{~V}$ involving the 2 electron-reaction or more. From a mechanistic point of view, zinc and water insertion are thought to be responsible for the formation of a $\mathrm{Zn}_{x} \mathrm{~V}_{2} \mathrm{O}_{5}, \mathrm{nH}_{2} \mathrm{O}$ compound $[25,27]$ or a zinc pyrovanadate $[27,28]$ upon cycling. After an activation process over several cycles (fewer than ten, to a few dozen at most), highly stable capacities with scattered values in the range $220-470 \mathrm{mAh} \mathrm{g}^{-1}$ are achieved.

Recently, the use of a binary electrolyte of Li and $\mathrm{Zn}$ salts in mild acidic electrolyte attracted great interest, leading to the concept of rechargeable aqueous hybrid electrolyte, which involves two separate electrochemical redox processes on $\mathrm{Zn}$ anode and cathode, respectively. The electrolyte acts as conducting ions and cooperates with electrodes, ensuring efficient cyclability of $\mathrm{Zn}$ anode as well as reversible lithium insertion-extraction in the host cathodic material. Chen et al. proposed the first hybrid $\mathrm{Zn}\left\|\mathrm{ZnCl}_{2}+\mathrm{LiCl}\right\| \mathrm{LiMn}_{2} \mathrm{O}_{4}$ system operating with high efficiency and long-term 
cyclability [30]. In addition to $\mathrm{LiMn}_{2} \mathrm{O}_{4}$, other cathode materials like $\mathrm{LiFePO}_{4}[31,32]$, $\mathrm{Li}_{3} \mathrm{~V}_{2}\left(\mathrm{PO}_{4}\right)_{3}$ [33], $\mathrm{LiVPO}_{4} \mathrm{~F}$ [34], $\mathrm{LiNi}_{1 / 3} \mathrm{Co}_{1 / 3} \mathrm{Mn}_{1 / 3} \mathrm{O}_{2}$ [35], $\mathrm{LiMn}_{0.8} \mathrm{Fe}_{0.2} \mathrm{PO}_{4}$ [36] have been investigated. High capacities in the range $100-130 \mathrm{mAh} \mathrm{g}^{-1}$ have been reported with good capacity retention upon cycling near $1.6 / 1.8 \mathrm{~V}$. A high rate capability is a common feature of such hybrid batteries with a 70-80\% capacity retention at $4 \mathrm{C}$.

We newly applied this concept of rechargeable aqueous hybrid batteries, using the conventional pristine $\alpha-\mathrm{V}_{2} \mathrm{O}_{5}$ oxide as cathode material and $\mathrm{Zn}$ as anode in $2.5 \mathrm{M}$ $\mathrm{Li}_{2} \mathrm{SO}_{4}+3.5 \mathrm{M} \mathrm{ZnSO}_{4}(\mathrm{pH}=4)$ binary electrolyte with a special emphasis on the structural mechanism involved upon discharge/charge process in the $1.6 \mathrm{~V}-0.8 \mathrm{~V}$ potential range (corresponding to the transfer of one-electron) [37]. The $\mathrm{Zn} \| 2.5 \mathrm{M}$ $\mathrm{Li}_{2} \mathrm{SO}_{4}+3.5 \mathrm{M} \mathrm{ZnSO}_{4} \| \alpha-\mathrm{V}_{2} \mathrm{O}_{5}$ cell delivered capacity values about $136-125 \mathrm{mAh} \mathrm{g}^{-1}$ at $\mathrm{C} / 20-\mathrm{C} / 5$ rates $\left(7.35-29.4 \mathrm{~mA} \mathrm{~g}^{-1}\right)$, respectively. At $1 \mathrm{C}\left(147 \mathrm{~mA} \mathrm{~g}^{-1}\right)$, a capacity of $80 \mathrm{mAh} \mathrm{g}^{-1}$ was outstandingly retained over more than 300 cycles. A detailed structural study by X-ray diffraction (XRD) and Raman spectroscopy allowed unravelling the peculiar response of the $\alpha-\mathrm{V}_{2} \mathrm{O}_{5}$ layered host lattice. Strong similarities with the wellknown structural changes reported in non-aqueous lithiated electrolytes were highlighted. The mitigated structural findings revealed a reaction mechanism mainly based on $\mathrm{Li}^{+}$intercalation but also suggested a possible cointercalation of $\mathrm{Zn}^{2+}$ cations or protons by the end of the discharge. The presence of a few zinc cations between the oxide layers were suggested to act as pillars stabilizing the structure upon cycling [37].

An exploratory approach for finding new advanced cathode materials in the vanadium oxide family consists in considering the interest of the various $\mathrm{V}_{2} \mathrm{O}_{5}$ polymorphs. Among them, $\gamma^{\prime}-\mathrm{V}_{2} \mathrm{O}_{5}$ was recently proved to be of great interest as an insertion compound, with attractive electrochemical features for $\mathrm{Li}$ and $\mathrm{Na}$-ion batteries [38-41]. In particular, the puckered layered lattice of $\gamma^{\prime}-\mathrm{V}_{2} \mathrm{O}_{5}$ allows 
reversible Li insertion in a higher voltage window by about $200 \mathrm{mV}$ than $\alpha-\mathrm{V}_{2} \mathrm{O}_{5}$ (3.6/3.5 V vs. 3.4/3.2 V vs. $\left.\mathrm{Li}^{+} / \mathrm{Li}\right)$. The structure of this polymorph consists of infinite ribbons made of $\mathrm{VO}_{5}$ edge-sharing distorted pyramids leading to larger interlayer spacing (5.02 $\AA$ in $\gamma^{\prime}-\mathrm{V}_{2} \mathrm{O}_{5}$ vs. $4.37 \AA$ in $\left.\alpha-\mathrm{V}_{2} \mathrm{O}_{5}\right)$, which enables an easier accommodation of guest cations.

However, in spite of such remarkable structural features, $\gamma^{\prime}-\mathrm{V}_{2} \mathrm{O}_{5}$ phase has never been studied in an aqueous battery. In this work, the electrochemical and structural behaviour of $\gamma^{\prime}-\mathrm{V}_{2} \mathrm{O}_{5}$ are depicted for the first time in an aqueous $\mathrm{Zn} l \mid \gamma^{\prime}-\mathrm{V}_{2} \mathrm{O}_{5}$ battery using a binary $2.5 \mathrm{M} \mathrm{Li}_{2} \mathrm{SO}_{4}+3.5 \mathrm{M} \mathrm{ZnSO}_{4}$ electrolyte. Electrochemical performances are investigated in two different voltage ranges $(1.6 \mathrm{~V}-1 \mathrm{~V}$ and $1.6 \mathrm{~V}-0.7 \mathrm{~V})$ and the structural response of the cathode material is investigated by XRD and Raman spectroscopy.

\section{Experimental}

\subsection{Synthesis}

$\gamma^{\prime}-\mathrm{V}_{2} \mathrm{O}_{5}$ was obtained by chemical oxidation of $\gamma-\mathrm{LiV}_{2} \mathrm{O}_{5}$ prepared by chemical lithiation of $\alpha-\mathrm{V}_{2} \mathrm{O}_{5}$ under mild-temperature conditions. Further details can be found in [39]. A very fine powder of $\alpha-\mathrm{V}_{2} \mathrm{O}_{5}$ with narrow particle size distribution was used as precursor, prepared using the polyol route [42]. The chemical reaction of $\alpha-\mathrm{V}_{2} \mathrm{O}_{5}$ with $\mathrm{LiI}$ in excess (molar ratio 2:1) in acetonitrile leads to $\delta-\mathrm{LiV}_{2} \mathrm{O}_{5}$. After drying at $70^{\circ} \mathrm{C}$, the $\delta-\mathrm{LiV}_{2} \mathrm{O}_{5}$ powder was heat-treated at $300^{\circ} \mathrm{C}$ for $3 \mathrm{~h}$ under vacuum in a Büchi furnace to form the distorted layered $\gamma-\mathrm{LiV}_{2} \mathrm{O}_{5}$ structure. The last step consists in extracting lithium ions from the interlayer spacing of $\gamma-\mathrm{LiV}_{2} \mathrm{O}_{5}$ without damaging the distorted host structure. This chemical oxidation reaction requires the use of the strong oxidizing agent $\mathrm{NO}_{2} \mathrm{BF}_{4}$ (molar ratio 1:4) in acetonitrile. The solution was stirred at room temperature for $4 \mathrm{~h}$. The obtained powder was washed 4 times with acetonitrile 
and acetone and then dried at $80^{\circ} \mathrm{C}$. The powder color changed from dark green to orange, which confirms the complete delithiation of the product. Electrochemical titration using galvanostatic oxidation and chemical redox titration confirmed the $5+$ oxidation state of vanadium in $\gamma^{\prime}-\mathrm{V}_{2} \mathrm{O}_{5}$.

\subsection{Electrochemical tests}

$\gamma^{\prime}-\mathrm{V}_{2} \mathrm{O}_{5}$ positive electrodes were prepared by mixing $90 \mathrm{wt} \%$ of active material, 6 wt\% polyvinylidene fluoride (PVDF, Kynar, HSV900) as a binder, 4 wt\% carbon black (Ketjen Black International Co., Japan) as conductive agent dissolved in 1methyl-2-pyrrolidinone (NMP, Sigma-Aldrich). The prepared slurry was casted on carbon paper (Alfa Aesar Co.), vacuum dried at $70{ }^{\circ} \mathrm{C}$ for $3 \mathrm{~h}$ and punched into disks of $8 \mathrm{~mm}$ in diameter. The mass loading of active material was around $6 \mathrm{mg} \mathrm{cm}^{-2}$. Zinc foil (Goodfellow, USA) was used as both negative and reference electrodes. The electrolyte was prepared by dissolving $3.5 \mathrm{M} \mathrm{ZnSO}_{4} 7 \mathrm{H}_{2} \mathrm{O}$ and $2.5 \mathrm{M} \mathrm{Li}_{2} \mathrm{SO}_{4}$ in distilled water and according to previous $\mathrm{pH}$ optimizations [31], the $\mathrm{pH}$ was adjusted to 4 by titration with $0.5 \mathrm{~mol} \mathrm{~L}^{-1} \mathrm{H}_{2} \mathrm{SO}_{4}$. Prepared electrolyte was bubbled with nitrogen gas $\left(\mathrm{N}_{2}\right)$ to remove dissolved oxygen. AGM (Absorptive Glass Mat NSG Corporation) was used as separator. The two-electrode cells were tested galvanostatically at various $\mathrm{C}$ rates ( $1 \mathrm{C}$ corresponds to $147 \mathrm{~mA} \mathrm{~g}^{-1}$ ) and by cyclic voltammetry (sweep rate $0.2 \mathrm{mV}$ $\mathrm{s}^{-1}$ ), using a VMP3 potentiostat/galvanostat (Bio-Logic Science Instrument Co.). The tests temperature was controlled at $20{ }^{\circ} \mathrm{C}$. All potentials are reported in $\mathrm{V}$ vs. $\mathrm{Zn} / \mathrm{Zn}^{2+}$. The structural investigation of the $\mathrm{Zn}\left\|\mathrm{Li}_{2} \mathrm{SO}_{4}-\mathrm{ZnSO}_{4}\right\| \gamma^{\prime}-\mathrm{V}_{2} \mathrm{O}_{5}$ system was investigated by using a two-electrode split cell (MTI company). The cells were discharged or charged to the required composition at $\mathrm{C} / 5$ rate $\left(29.4 \mathrm{~mA} \mathrm{~g}^{-1}\right)$. Then after disassembling the cell, the positive electrodes were rinsed in distilled water in order to 
remove the traces of salt and separator, and then analyzed by XRD and Raman spectroscopy.

\subsection{Characterizations}

XRD measurements were carried out using a Panalytical X'pert pro diffractometer equipped with an X'celerator detector and a Co $K \alpha$ radiation (wavelength $1.7889 \AA$ ). All the diffraction patterns were collected with a $2 \theta$ step of $0.0167^{\circ}$. The Raman spectra were measured with a LaBRAM HR 800 (Jobin-Yvon-Horiba) Raman microspectrometer including Edge filters and equipped for signal detection with a back illuminated charge coupled device detector (Spex CCD) cooled by Peltier effect to 200 K. A He:Ne laser $(632.8 \mathrm{~nm})$ was used as the excitation source. The spectra were measured in back-scattering geometry. The resolution was about $0.5 \mathrm{~cm}^{-1}$. A $50 \mathrm{X}$ LWD objective was used to focus the laser light on sample surface to a spot size of $1 \mu \mathrm{m}^{2}$. To avoid local heating of the sample, the power of the laser beam was adjusted to $0.2-0.5 \mathrm{~mW}$ with neutral filters of various optical densities. Raman spectra were recorded on ten different spots of each electrode to check the homogeneity. The pristine powder and the electrodes were characterized by scanning electron microscopy (SEM), Zeiss, Merlin-type microscope. Electron Dispersive X-ray (EDX) analysis was applied to determine the elemental composition together with SEM with an accelerating voltage of $10-15 \mathrm{kV}$

\section{Results and discussion}

\subsection{Structural characterization of $\gamma^{\prime}-\mathrm{V}_{2} \mathrm{O}_{5}$}

SEM micrographs of the as-synthesized $\gamma^{\prime}-\mathrm{V}_{2} \mathrm{O}_{5}$ powder (Fig. 1) reveals a homogeneous grain size distribution made of porous aggregates of small platelets in the range $100-500 \mathrm{~nm}$. The $\mathrm{XRD}$ pattern of the as-synthesized $\gamma^{\prime}-\mathrm{V}_{2} \mathrm{O}_{5}$ powder is shown in Fig. 2a. All the reflection lines can be indexed in an orthorhombic symmetry (JCPDS Card No. 01-085-2422, Pnma space group) leading to the following unit cell 
parameters: $a=9.93(9) \AA, b=3.58(3) \AA, c=10.04(0) \AA$ in agreement with literature data [41]. The Rietveld refinement of the XRD pattern (Fig. S1) confirms the presence of a pure and well-crystallized single phase. The layered structure of $\gamma^{\prime}-\mathrm{V}_{2} \mathrm{O}_{5}$ is composed of infinite ribbons parallel to the $b$ axis made of $\mathrm{VO}_{5}$ edges-sharing distorted pyramids oriented alternatively up and down (inset in Fig.2a). These ribbons are linked to each other along the $a$-direction by one pyramid corner oxygen forming puckered layers perpendicular to the $c$-axis. The mean crystallite size estimated from diffraction peaks width is $90-100 \mathrm{~nm}$.

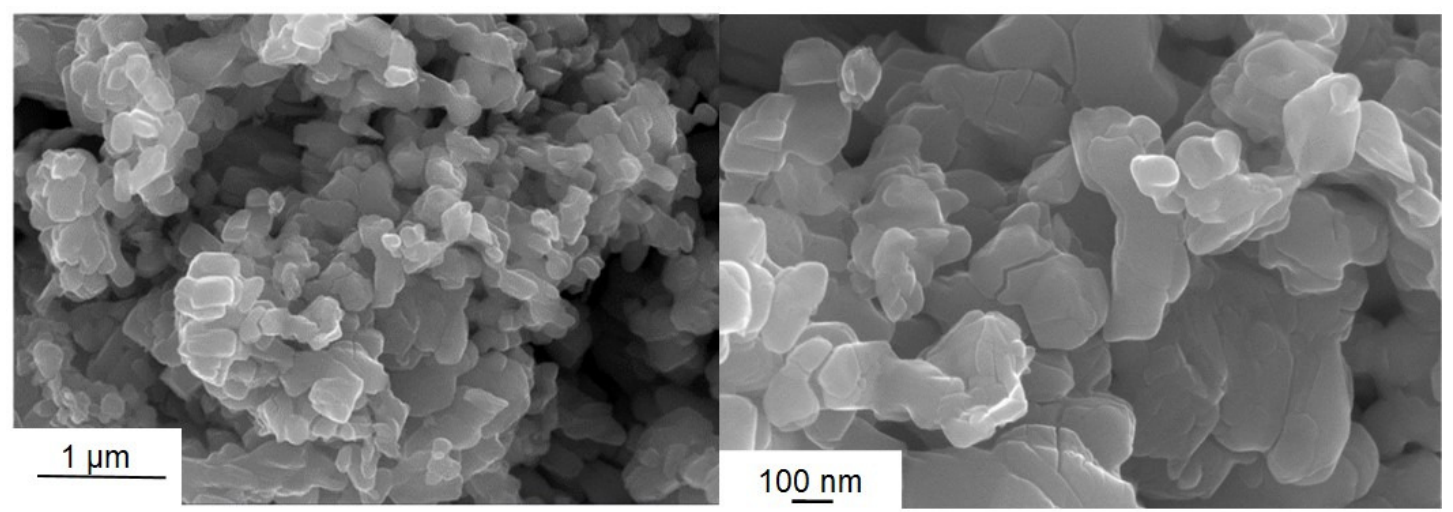

Fig. 1. SEM micrographs of as-prepared $\gamma^{\prime}-\mathrm{V}_{2} \mathrm{O}_{5}$ powder.

The Raman spectrum of $\gamma^{\prime}-\mathrm{V}_{2} \mathrm{O}_{5}$ is shown in Fig. $2 \mathrm{~b}$. The projection of the $\gamma^{\prime}-\mathrm{V}_{2} \mathrm{O}_{5}$ structure along the $b$-crystallographic direction showing all the $\mathrm{V}-\mathrm{O}$ contacts in the two non-equivalent vanadium environments $\left(\mathrm{V}_{\mathrm{a}}, \mathrm{V}_{\mathrm{b}}\right)$ is shown in inset of Fig. 2b. This Raman fingerprint fully agrees with previous study [38]. The whole vibrations of the chains are identified as follows: bands at 1037,1021 and $1003 \mathrm{~cm}^{-1}$ correspond to the stretching modes of the shortest $\mathrm{V}_{\mathrm{a}}-\mathrm{O}_{1 \mathrm{a}}$ and $\mathrm{V}_{\mathrm{b}}-\mathrm{O} 1_{\mathrm{b}}$ bonds, bands at 752 and $603 \mathrm{~cm}^{-1}$ are related to the bond stretching vibrations localized within the $\mathrm{V}_{\mathrm{a}}-\mathrm{O}_{3}-\mathrm{V}_{\mathrm{b}}$ bridges. The stretching modes of the $\mathrm{V}_{\mathrm{a}}-\mathrm{O}_{2 \mathrm{a}}-\mathrm{V}_{\mathrm{a}}$ and $\mathrm{V}_{\mathrm{b}}-\mathrm{O}_{2 \mathrm{~b}}-\mathrm{V}_{\mathrm{b}}$ bridges forming the rails of the ladders are observed at 722 and $694 \mathrm{~cm}^{-1}$. Modes involving the $\mathrm{V}_{\mathrm{a}}-\mathrm{O}_{2 \mathrm{a}}$ and $\mathrm{V}_{\mathrm{b}}-\mathrm{O}_{2 \mathrm{~b}}$ ladder step bonds (indicated by dashed line) are seen at 532 and $500 \mathrm{~cm}^{-1}$. The lower 
frequency modes at $92,126,138,153,171,190,238,266,282,299,349$ and $390 \mathrm{~cm}^{-}$

${ }^{1}$ correspond to the complex distortions of the $\mathrm{V}_{2} \mathrm{O}_{5}$ ladders [38].
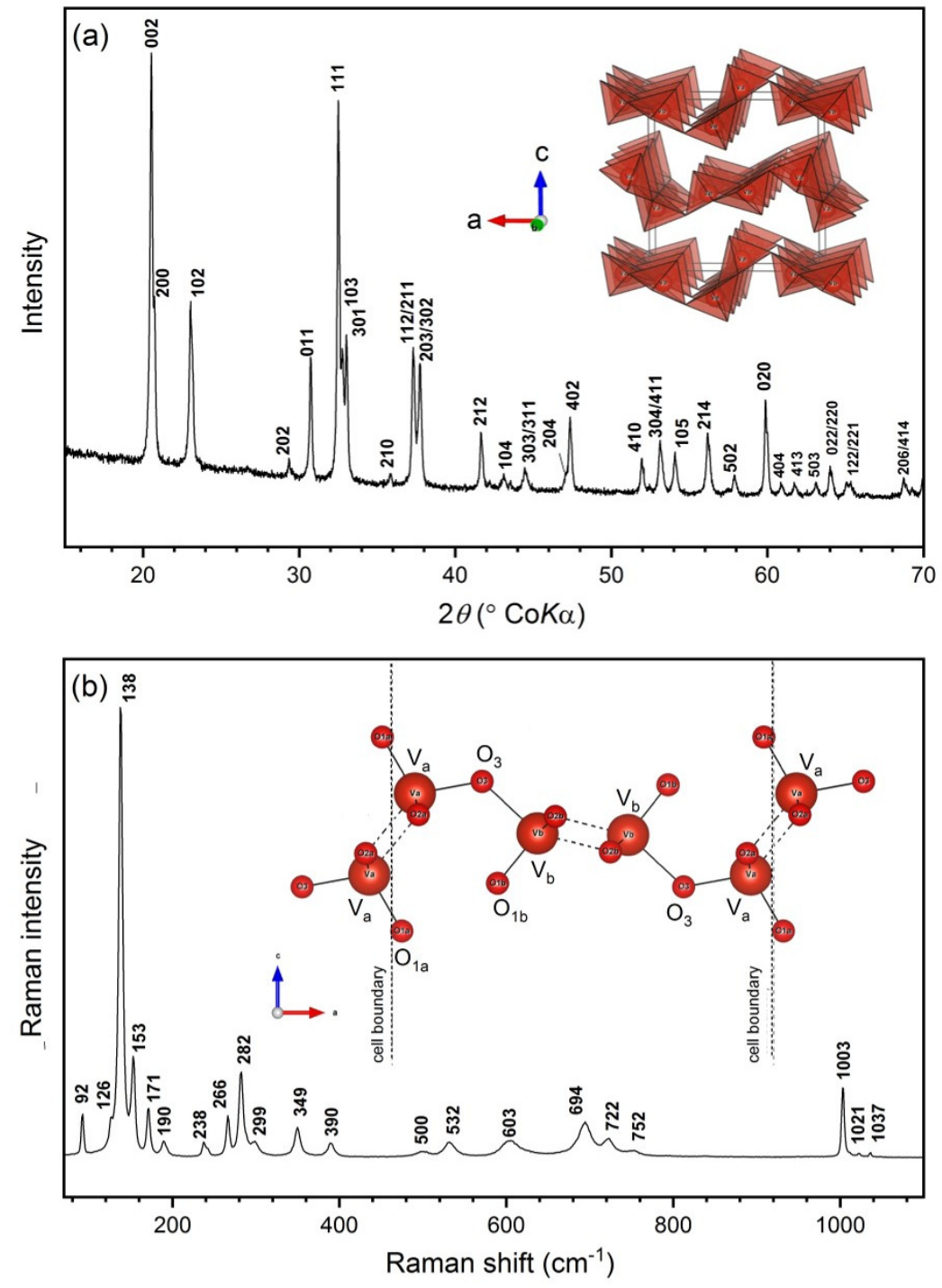

Fig. 2. (a) X-ray diffraction pattern of $\gamma^{\prime}-\mathrm{V}_{2} \mathrm{O}_{5}$ powder. Inset: crystal structure of $\gamma^{\prime}-\mathrm{V}_{2} \mathrm{O}_{5}$ (b) Raman spectrum of $\gamma^{\prime}-\mathrm{V}_{2} \mathrm{O}_{5}$ powder. Inset: projection of the structure of $\gamma^{\prime}-\mathrm{V}_{2} \mathrm{O}_{5}$ along the $b$-crystallographic direction showing all the $\mathrm{V}-\mathrm{O}$ contacts. Dashed lines show $\mathrm{V}$ - O interchain contacts (ladder-step bonds)

\subsection{Electrochemical study and structural mechanism in the $1.6 \mathrm{~V}-1.0 \mathrm{~V}$ potential range}

The first cyclic voltammetric curve of $\gamma^{\prime}-\mathrm{V}_{2} \mathrm{O}_{5}$ (black curve in Fig. 3a) indicates that the electrochemical reaction is characterized by two distinct redox processes. Indeed, two cathodic peaks are observed at $1.32 \mathrm{~V}$ and $1.22 \mathrm{~V}$ with their corresponding reversible anodic peaks at $1.46 \mathrm{~V}$ and $1.31 \mathrm{~V}$, respectively. The coulombic charge 
involved upon cathodic scan corresponds to $\approx 0.8 \mathrm{~F} / \mathrm{mol}$ of oxide and the same amount of electricity is engaged during the reverse scan, showing the excellent reversibility of electrochemical processes. The first discharge-charge profile of $\gamma^{\prime}-\mathrm{V}_{2} \mathrm{O}_{5}$ at $\mathrm{C} / 5$ rate in the $1.6 \mathrm{~V}-1.0 \mathrm{~V}$ potential range is shown in Fig. 3b. Similarly, the discharge curve exhibits two steps involving a total faradaic yield of $0.8 \mathrm{~F} \mathrm{~mol}^{-1}$ (specific capacity of $120 \mathrm{mAh} \mathrm{g}^{-1}$ ). The voltage plateau at $1.38 \mathrm{~V}$ is related to the two sharp voltammetric peaks at 1.32/1.46 $\mathrm{V}$ and suggests a two-phase behavior, while the sloping curve centered near $1.27 \mathrm{~V}$ seems to indicate a single-phase redox process. A quantitative charge process is achieved, with only $30 \mathrm{mV}$ hysteresis between discharge and charge, i.e. half that observed for $\alpha-\mathrm{V}_{2} \mathrm{O}_{5}$. It is worth noting the higher operating voltage $(\approx+$ $200 \mathrm{mV}$ ) of $\gamma^{\prime}-\mathrm{V}_{2} \mathrm{O}_{5}$ compared with $\alpha-\mathrm{V}_{2} \mathrm{O}_{5}$ (red dotted curves in Fig. 3), as observed in organic lithiated electrolyte [40], which outlines the interest of the puckered polymorph as cathode material in aqueous electrolyte. In addition, the present electrochemical fingerprint of $\gamma^{\prime}-\mathrm{V}_{2} \mathrm{O}_{5}$ closely resembles that known in non-aqueous lithiated electrolyte [40]. This suggests a similar reaction mechanism is involved in binary $\mathrm{Li}_{2} \mathrm{SO}_{4} / \mathrm{ZnSO}_{4}$ electrolyte.
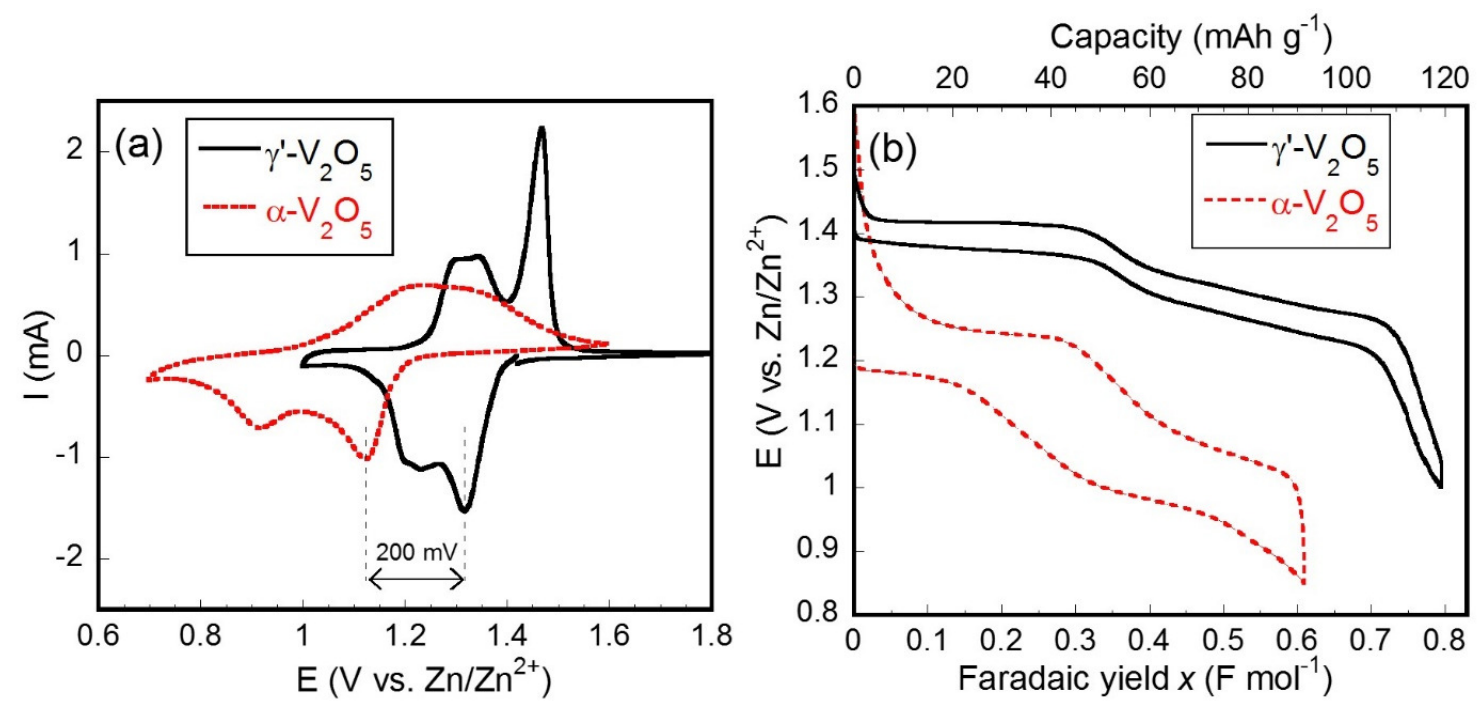

Fig. 3. (a) Cyclic voltammograms (scanning rate $0.2 \mathrm{mV} \mathrm{s}^{-1}$ ) and (b) first galvanostatic cycles at $\mathrm{C} / 5$ rate of $\gamma^{\prime}-\mathrm{V}_{2} \mathrm{O}_{5}$ (black curves) and $\alpha-\mathrm{V}_{2} \mathrm{O}_{5}$ (red dotted curves). 
To address this issue, we have investigated the structural response of $\gamma^{\prime}-\mathrm{V}_{2} \mathrm{O}_{5}$ during the first discharge-charge cycle at $\mathrm{C} / 5$ in the $1.6 \mathrm{~V}-1.0 \mathrm{~V}$ potential range, using XRD and Raman spectroscopy. The XRD patterns of reduced electrodes as a function of the faradaic yield $x$ (in $\mathrm{F} \mathrm{mol}^{-1}$ ), $0 \leq x \leq 0.72$, are shown in Fig. 4 . The XRD pattern of the pristine electrode $(x=0)$ shows the typical fingerprint of orthorhombic $\gamma^{\prime}-\mathrm{V}_{2} \mathrm{O}_{5}($ Pnma space group) with the unit cell parameters of the pristine powder ( $a=9.94 \AA$, $b=3.58$ $\AA, c=10.04 \AA$ ). From the very first reduction rate $(x=0.1)$, a new set of 002,102 , 103 and 214 diffraction lines are detected at 19.95, 22.5, 32.0 and 55.3 ${ }^{\circ}$, respectively, that coexist with those of the initial $\gamma^{\prime}-\mathrm{V}_{2} \mathrm{O}_{5}$ material. This new set of lines is indexed in an orthorhombic symmetry (Pnma space group) and reveals the emergence of a lithiated $\gamma-\mathrm{Li}_{x} \mathrm{~V}_{2} \mathrm{O}_{5}$ phase. The same comment can be made for $x=0.2$, with the new lines increasing at the expense of those related to the pristine compound. The shifts toward lower $2 \theta$ values for the 002, 102, 103, 104, 204, 105 and 214 reflections and to higher $2 \theta$ one for the 200 line clearly indicate an expansion in the $c$ interlayer distance and a contraction in a parameter, respectively. Indeed, the unit cell parameters calculated for the reduced $\gamma-\mathrm{Li}_{x} \mathrm{~V}_{2} \mathrm{O}_{5}$ phases $(x=0.1 ; 0.2)$ are $a=9.83 \AA, b=3.59 \AA$, $c=10.34 \AA$ Arom $x=0.35$, this trend is maintained: all the diffraction lines belong to the lithiated phase with a continuous shift of the 002 and 200 reflection lines toward higher and lower $2 \theta$ values, respectively, indicating a continuous expansion of $c$ interlayer parameter and shrinkage in $a$ parameter. In the $0.35 \leq x \leq 0.72$ composition range, the diffraction patterns show the existence of a single phase with cell parameters changing linearly with the depth of discharge. The unit cell parameters for the fully reduced $\gamma-\mathrm{Li}_{0.72} \mathrm{~V}_{2} \mathrm{O}_{5}$ electrode $(a=9.69 \AA, b=3.60 \AA, c=10.67 \AA$ ) match very well those reported for $\gamma-\mathrm{Li}_{1} \mathrm{~V}_{2} \mathrm{O}_{5}$ formed during electrochemical lithiation of $\gamma^{\prime}-\mathrm{V}_{2} \mathrm{O}_{5}$ in non-aqueous lithiated electrolyte ( $a=9.71 \AA, b=3.61 \AA$ and $c=10.67 \AA$ ) [40]. It is 
also worth noting the similarity of the unit cell variations vs. composition in aqueous and non-aqueous electrolytes [40]. Such findings are well consistent with a pure Li insertion reaction and enable us to rebut the hypothesis of water molecules, zinc or proton insertion into the $\gamma^{\prime}-\mathrm{V}_{2} \mathrm{O}_{5}$ host lattice.

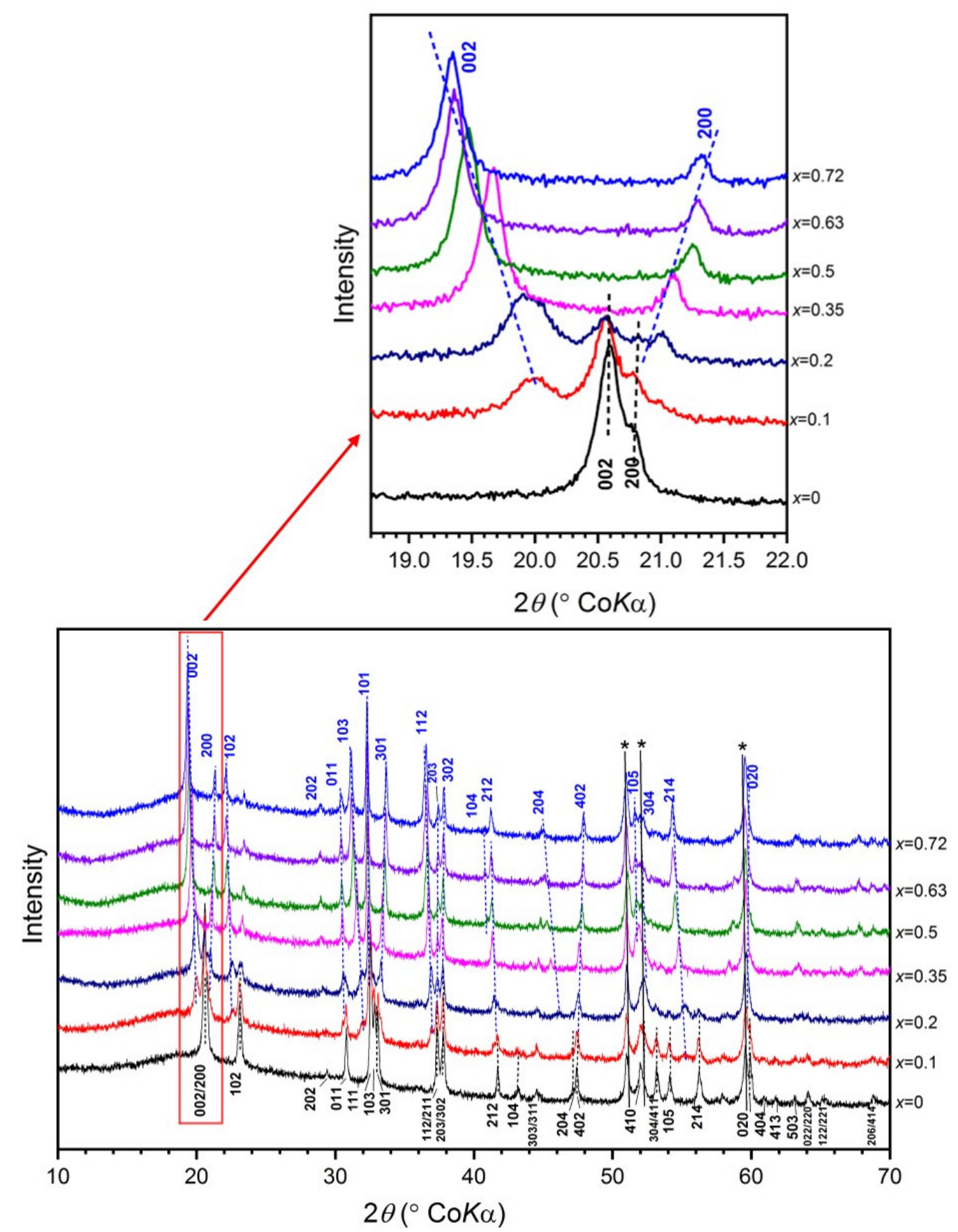

Fig. 4. X-ray diffraction patterns of reduced $\gamma^{\prime}-\mathrm{V}_{2} \mathrm{O}_{5}$ electrodes during the first discharge at $\mathrm{C} / 5$ as a function of the faradaic yield $x\left(\mathrm{~F} \mathrm{~mol}^{-1}\right) .0 \leq x \leq 0.72$. *: sample holder (stainless steel) reflections. 1.6 V - $1 \mathrm{~V}$ voltage window 
The detailed lattice parameters evolutions as a function of $x$ in $\gamma-\mathrm{Li}_{x} \mathrm{~V}_{2} \mathrm{O}_{5}$ during the first discharge $(0 \leq x \leq 0.72)$ are depicted in Fig. 5. Two main domains clearly appear. First, a diphasic region for $0<x<0.35$ where $\gamma^{\prime}-\mathrm{V}_{2} \mathrm{O}_{5}$ coexists with a lithiated phase $\gamma-\mathrm{Li}_{\mathrm{x}} \mathrm{V}_{2} \mathrm{O}_{5}$ characterized by a slight interlayer expansion of $3 \%$ (Fig. $5 \mathrm{c}$ ) and a very low contraction of $1 \%$ along the $a$ direction (Fig. 5a). On further reduction $(0.35 \leq x \leq$ 0.72), a single-phase region is evidenced with a negligible $b$ variation of $0.3 \%$ (Fig. $5 b)$, a minor contraction in $a$ parameter $(1 \%)$ and a moderate expansion in $c$ parameter (3\%), showing the puckered layered arrangement of $\gamma^{\prime}-\mathrm{V}_{2} \mathrm{O}_{5}$ is not altered upon $\mathrm{Li}$ insertion. The negligible change in $b$ parameter is consistent with a $\mathrm{Li}$ diffusion occurring along the $b$ direction.
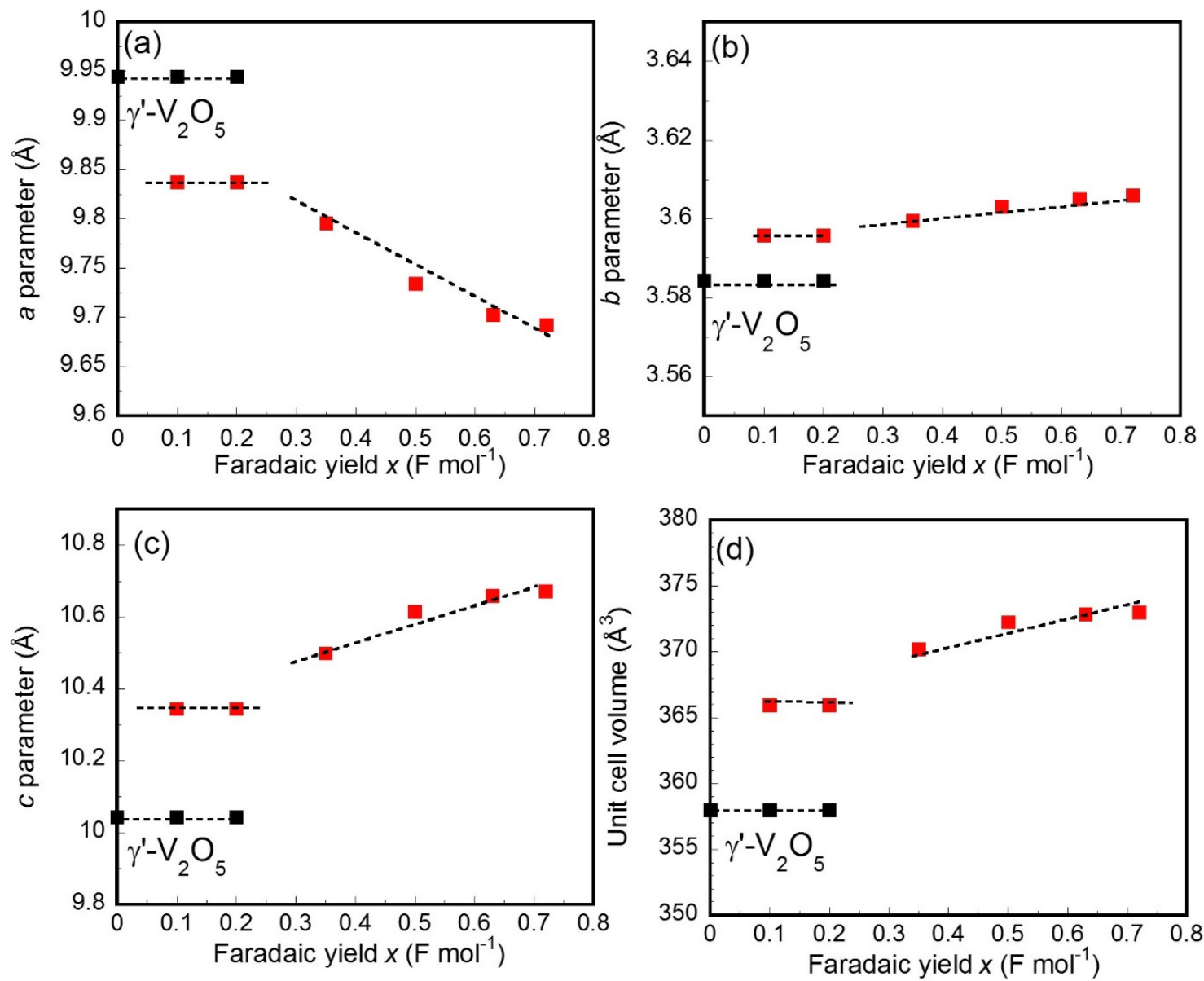

Fig. 5. Evolution of the unit cell parameters $a, b, c$ and unit cell volume of reduced $\gamma^{\prime}-$ $\mathrm{V}_{2} \mathrm{O}_{5}$ electrodes during the first discharge at $\mathrm{C} / 5$ as a function of the faradaic yield $x$ $\left(\mathrm{F} \mathrm{mol}^{-1}\right) .0 \leq x \leq 0.72$. Black squares: $\gamma^{\prime}-\mathrm{V}_{2} \mathrm{O}_{5}$; red squares: new phase. 
The Raman spectra of reduced electrodes as a function of the faradaic yield $x, 0 \leq$ $x \leq 0.72$, are gathered in Fig. 6. As the reduction rate increases in the $0<x \leq 0.5$ composition range, the Raman spectra undergo progressive changes in intensity or position while new bands are observed. These changes can be depicted as follows: the relative intensity of bands belonging to the pristine $\gamma^{\prime}-\mathrm{V}_{2} \mathrm{O}_{5}$ material, at $91,138,153$, $190,238,282,299,349,500,603,694,1003$ and $1037 \mathrm{~cm}^{-1}$ gradually decreases up to their total disappearance for $x=0.5$. At the same time, new peaks (indicated by blue open circles) belonging to the electroformed phase are detected, with increasing relative intensity as the reduction rate increases: at $990 \mathrm{~cm}^{-1}$ (from $x=0.1$ ), $462 \mathrm{~cm}^{-1}$ (from $x=0.35$ ), 100, 124, 331 and $966 \mathrm{~cm}^{-1}$ (from $x=0.5$ ). Finally, three bands belonging to both systems are kept all along the reduction process but undergo continuous wavenumber shifts: 266 to $272 \mathrm{~cm}^{-1}, 722$ to $731 \mathrm{~cm}^{-1}, 1021$ to $1014 \mathrm{~cm}^{-1}$. For $x=0.35$, the Raman spectrum is modified, showing mostly the bands of the electroformed phase with only traces of the pristine oxide through the presence of low features at 138,159,171, 266, 282, 299 and $694 \mathrm{~cm}^{-1}$. This is due to the very high Raman scattering cross section of $\gamma^{\prime}-\mathrm{V}_{2} \mathrm{O}_{5}$ [38]. For $x=0.5$, the Raman spectrum is characteristic of the pure new system with bands at 100, 124, 171, 272, 331, 374, 462, $531,642,731,966,990$ and $1014 \mathrm{~cm}^{-1}$. For $0.5 \leq x \leq 0.72$, the fingerprint of the new phase dominates the Raman spectrum. An ultimate feature appears at $642 \mathrm{~cm}^{-1}$ for the fully reduced sample while the $966 \mathrm{~cm}^{-1}$ peak increases in intensity. Such trends indicate the existence of a diphasic region in the composition range $0<x<0.35$, in which the pristine $\gamma^{\prime}-\mathrm{V}_{2} \mathrm{O}_{5}$ phase disappears progressively while a new system emerges, followed by a single-phase region of the pure new system for $x \geq 0.35$. The Raman fingerprint of the electroformed phase matches perfectly that reported for $\gamma$ $\mathrm{Li}_{1} \mathrm{~V}_{2} \mathrm{O}_{5}$ formed during electrochemical lithiation of $\gamma^{\prime}-\mathrm{V}_{2} \mathrm{O}_{5}$ in non-aqueous lithiated 
electrolyte [40] as well as chemically synthesized $\gamma-\mathrm{LiV}_{2} \mathrm{O}_{5}$ [43]. The whole assignment of the Raman spectrum of the $\gamma-\mathrm{LiV}_{2} \mathrm{O}_{5}$ bronze can be found in [43]. Examination of the charged electrodes by XRD and Raman spectroscopy (Fig. S2) shows the complete restoration of the $\gamma^{\prime}-\mathrm{V}_{2} \mathrm{O}_{5}$ host lattice after one discharge-charge cycle, both at the long-range order and atomic scale, with no extra peak or band related to the presence of another phase. Such findings explain the good electrochemical reversibility displayed in Fig. 3.

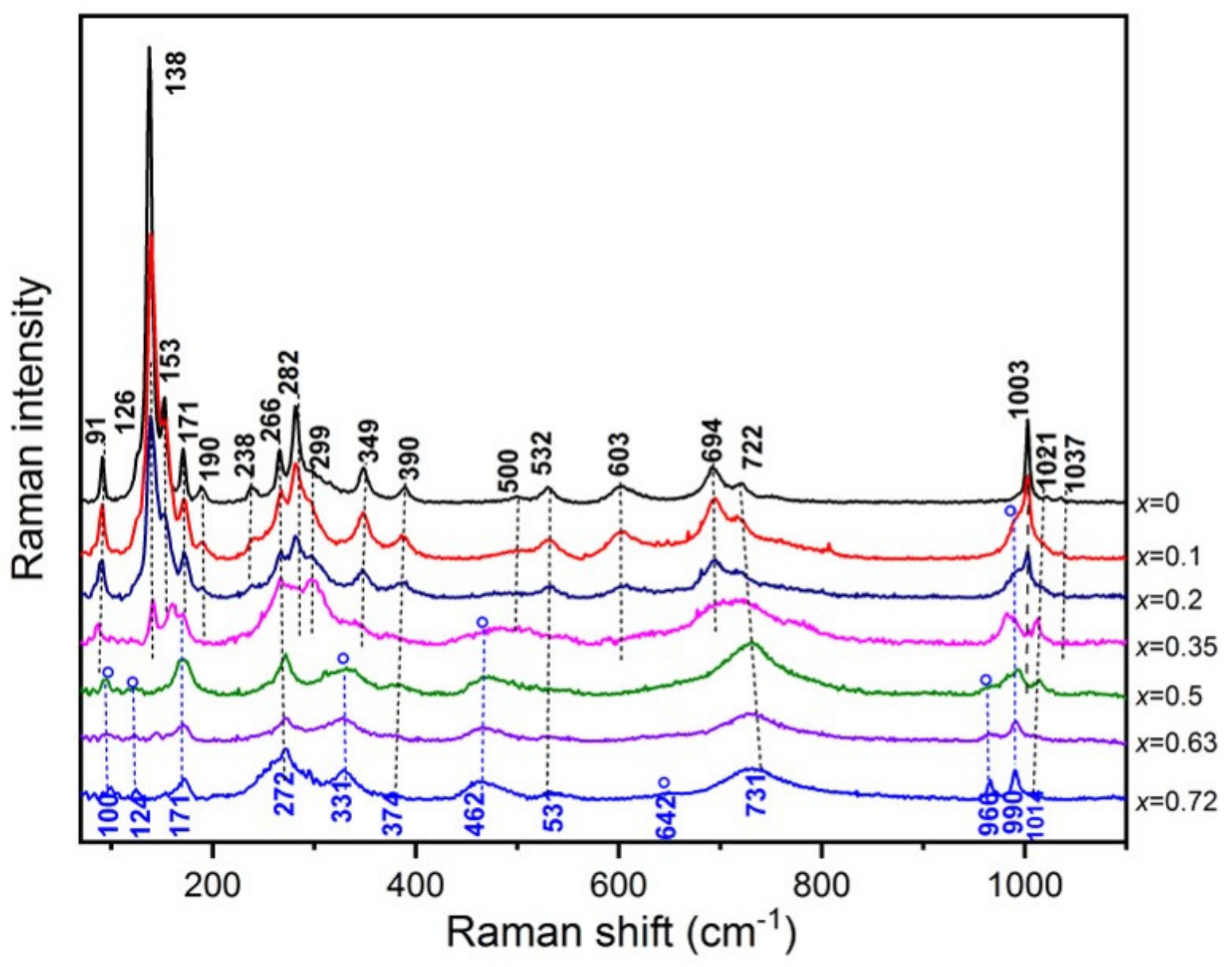

Fig. 6. Raman spectra of reduced $\gamma^{\prime}-\mathrm{V}_{2} \mathrm{O}_{5}$ electrodes during the first discharge at $\mathrm{C} / 5$ as a function of the faradaic yield $x\left(\mathrm{~F} \mathrm{~mol}^{-1}\right) .0 \leq x \leq 0.72 .1 .6 \mathrm{~V}-1 \mathrm{~V}$ voltage window.

These structural data drawn from XRD and Raman spectroscopy reveal that $\gamma^{\prime}-\mathrm{V}_{2} \mathrm{O}_{5}$ electrodes selectively intercalate $\mathrm{Li}^{+}$ions upon discharge. The nature of structural changes of the $\gamma^{\prime}-\mathrm{V}_{2} \mathrm{O}_{5}$ host lattice as well their magnitude exclude any 
participation of proton, zinc ions or water molecules. Instead, we highlight a reversible reaction mechanism, very similar to that reported in non-aqueous electrolyte [40], involving a diphasic domain for $0<x<0.35$ with coexistence of $\gamma^{\prime}-\mathrm{V}_{2} \mathrm{O}_{5}$ and $\gamma$ $\mathrm{Li} \approx 0.3 \mathrm{~V}_{2} \mathrm{O}_{5}$, followed by a solid solution region $\gamma-\mathrm{Li}_{x} \mathrm{~V}_{2} \mathrm{O}_{5}$ for $0.35 \leq x \leq 0.72$.

Preliminary rate capability study indicates a promising behaviour since the specific capacity is little affected with increasing $\mathrm{C}$ rate (Fig. S3). Indeed the discharge capacity decreases from $120 \mathrm{mAh} \mathrm{g}^{-1}$ at $\mathrm{C} / 5$ to 105 and $95 \mathrm{mAh} \mathrm{g}^{-1}$ at $1 \mathrm{C}$ and $5 \mathrm{C}$, respectively. In addition, the low hysteresis achieved between the charge and discharge, $60 \mathrm{mV}$ at $1 \mathrm{C}$ and $100 \mathrm{mV}$ at $5 \mathrm{C}$, are quite remarkable. In spite of these promising performances, electrochemical experiments in the $1.6 \mathrm{~V}-1 \mathrm{~V}$ voltage window do not allow to reach a specific capacity larger than $120 \mathrm{mAh} \mathrm{g}^{-1}$, value that is much less than those usually reported for vanadium-based cathode materials [7-29]. In order to increase the available capacity, we have extended the voltage window by lowering the cutoff voltage to $0.7 \mathrm{~V}$ and investigated the electrochemical properties and related structural changes of $\gamma^{\prime}-\mathrm{V}_{2} \mathrm{O}_{5}$ in this enlarged voltage range.

\subsection{Electrochemical study and structural mechanism in the enlarged $1.6 \mathrm{~V}-0.7 \mathrm{~V}$} potential range

The successive discharge-charge cycles of $\gamma^{\prime}-\mathrm{V}_{2} \mathrm{O}_{5}$ at $1 \mathrm{C}$ rate are displayed in Fig. 7a. The first cycle exhibits the typical reversible fingerprint of $\gamma^{\prime}-\mathrm{V}_{2} \mathrm{O}_{5}$ with two high voltage discharge steps at $1.36 \mathrm{~V}$ and $1.25 \mathrm{~V}$ followed by a potential drop, a total faradaic yield of $0.96 \mathrm{~F} \mathrm{~mol}^{-1}$ being involved. A careful examination of the first cycle shows however the presence of an additional ill-defined step near $0.9 \mathrm{~V}$. The contribution of this lower voltage contribution increases with cycles, from about $0.13 \mathrm{~F} \mathrm{~mol}^{-1}$ for the first cycle to $0.3 \mathrm{~F} \mathrm{~mol}^{-1}$ for the second one and $0.65 \mathrm{~F} \mathrm{~mol}^{-1}$ for cycle 4 , the total discharge capacity increasing significantly from 143 to $187 \mathrm{mAh} \mathrm{g}^{-1}$. 
At the same time, the contribution of the two high voltage steps decreases progressively to completely disappear for cycle 10 , which exhibits a sloping voltage profile involving a capacity value of $185 \mathrm{mAh} \mathrm{g}^{-1}$.
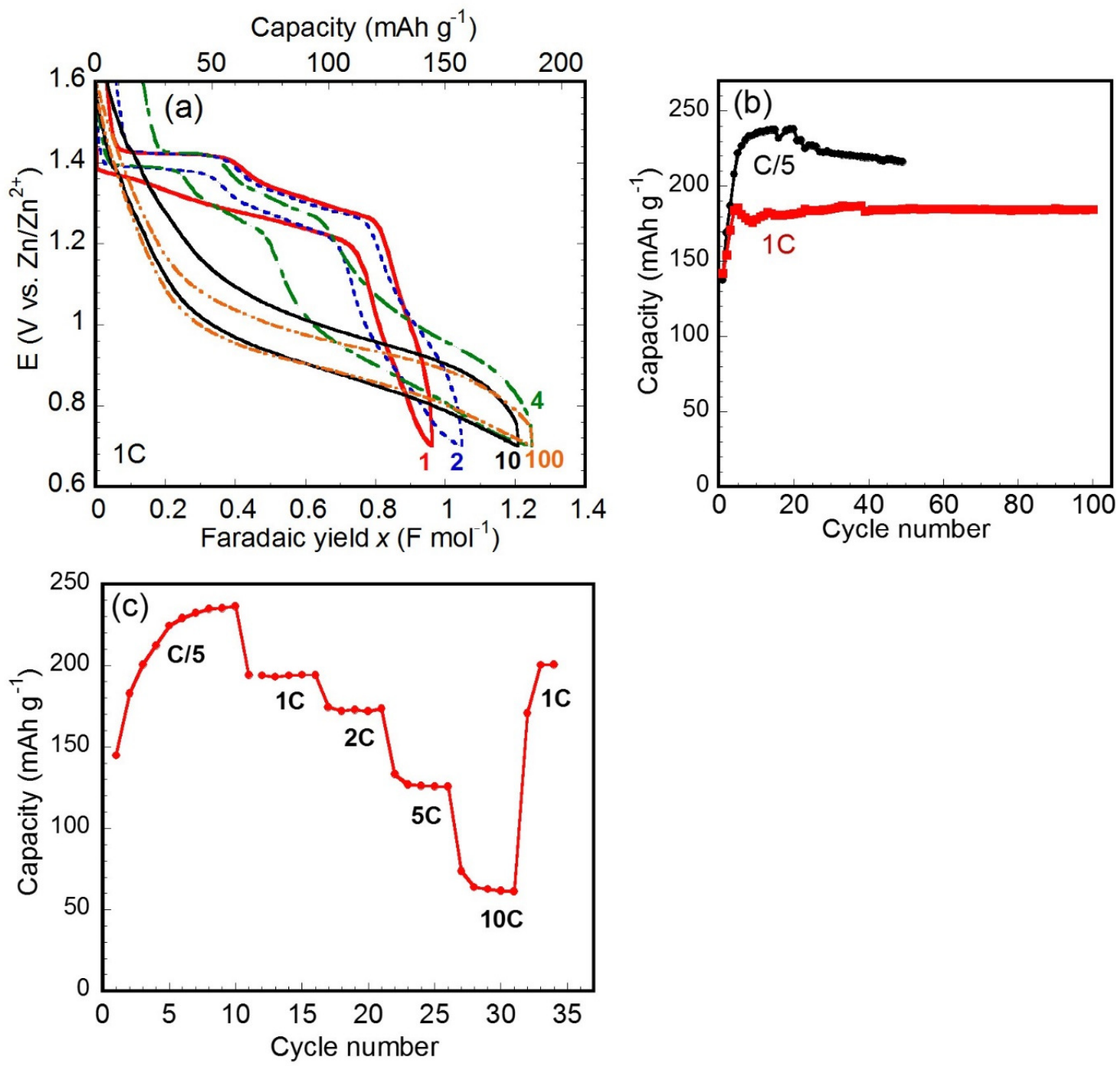

Fig. 7. Electrochemical performance of $\gamma^{\prime}-\mathrm{V}_{2} \mathrm{O}_{5}$ in the extended $1.6 \mathrm{~V}-0.7 \mathrm{~V}$ voltage window: (a) Discharge-charge cycles at $1 \mathrm{C}$ rate; (b) Evolution of the specific capacity as a function of the number of cycles at $\mathrm{C} / 5$ and $1 \mathrm{C}$ rates; (c) Rate capability study

Cycling tests (Fig. 7b) show a remarkable capacity retention of $97 \%$ at least over 100 cycles. A similar activation process is observed at C/5 rate (Fig. S4). Indeed, the capacity increases from 140 to $240 \mathrm{mAh} \mathrm{g}^{-1}$ along the ten first cycles, then stabilizes at $240 \mathrm{mAh} \mathrm{g}^{-1}$ over at least 50 cycles. This high stable capacity of $240 \mathrm{mAh} \mathrm{g}^{-1}$ competes 
very well with previous values reported for $\mathrm{V}_{2} \mathrm{O}_{5}$ using only a $\mathrm{Zn}$ salt $[23,26,28]$. It is noteworthy the reproducible discharge profile displayed from cycle 10, with completely superimposed reversible charge process, does not exhibit anymore the typical $\mathrm{Li}$ insertion steps of $\gamma^{\prime}-\mathrm{V}_{2} \mathrm{O}_{5}$. This suggests the lowering of the voltage window at $0.7 \mathrm{~V}$ induces a strong structural rearrangement. The redox process below $1 \mathrm{~V}$ involves a capacity that increases from 20 to $90 \mathrm{mAh} \mathrm{g}^{-1}$ during the five first cycles at $1 \mathrm{C}$ while the capacity contribution related to $\mathrm{Li}$ insertion in the upper voltage window $(1.6 \mathrm{~V}-1 \mathrm{~V})$ decreases from 123 to $97 \mathrm{mAh} \mathrm{g}^{-1}$. This trend is then confirmed up to cycle 10 with the $1.6 \mathrm{~V}-1 \mathrm{~V}$ contribution still decreasing to only $50 \mathrm{mAh} \mathrm{g}^{-1}$ for the benefit of the low voltage part that reaches $120 \mathrm{mAh} \mathrm{g}^{-1}$ after the activation process. Since further lithiation is expected to occur around $1 \mathrm{~V}$ lower than the high voltage steps, i.e. at about $0.4 \mathrm{~V}[40], \mathrm{Zn}^{2+}$ and/or proton insertion is probably involved below $1 \mathrm{~V}$, leading to a progressive capacity gain and change in the discharge-charge profile during the first activation cycles.

The rate capability behaviour of $\gamma^{\prime}-\mathrm{V}_{2} \mathrm{O}_{5}$ has been investigated in the $\mathrm{C} / 5-10 \mathrm{C}$ range, after performing an activation process of 10 cycles at $\mathrm{C} / 5$ (Fig. 7c and S5). Interesting capacities are reached: the stabilized capacity of $235 \mathrm{mAh} \mathrm{g}^{-1}$ at $\mathrm{C} / 5$ decreases moderately to $190 \mathrm{mAh} \mathrm{g}^{-1}$ at $1 \mathrm{C}, 170 \mathrm{mAh} \mathrm{g}^{-1}$ at $2 \mathrm{C}$, still $130 \mathrm{mAh} \mathrm{g}^{-1}$ at $5 \mathrm{C}$ and $65 \mathrm{mAh} \mathrm{g}^{-1}$ at $10 \mathrm{C}$. Even after sustaining high $10 \mathrm{C}$ rate, the cathode material is not damaged since the high capacity of about $200 \mathrm{mAh} \mathrm{g}^{-1}$ is recovered at $1 \mathrm{C} \mathrm{(Fig.} \mathrm{7c).}$ Far superior cycling performance are found here for $\gamma^{\prime}-\mathrm{V}_{2} \mathrm{O}_{5}$ compared to those recently reported for the conventional $\alpha-\mathrm{V}_{2} \mathrm{O}_{5}$ form in the same binary $\mathrm{Li} / \mathrm{Zn}$ electrolyte and same voltage range. Indeed, a stable capacity of only $80 \mathrm{mAh} \mathrm{g}^{-1}$ was achieved upon cycling $\alpha-\mathrm{V}_{2} \mathrm{O}_{5}$ at $1 \mathrm{C}$ [37] against $180-190 \mathrm{mAh} \mathrm{g}{ }^{-1}$ here for $\gamma^{\prime}-\mathrm{V}_{2} \mathrm{O}_{5}$. This huge improvement in capacity value shows the porous puckered polymorph $\gamma^{\prime}-$ 
$\mathrm{V}_{2} \mathrm{O}_{5}$ exhibits a more suitable structure towards zinc insertion, promoting then the electrochemical reaction. The promoting effect of a binary electrolyte on electrochemical performance of $\gamma^{\prime}-\mathrm{V}_{2} \mathrm{O}_{5}$ in a $\mathrm{Zn}$ battery is highlighted in Fig. S6 showing a sharp capacity decrease in the pure $\mathrm{ZnSO}_{4}$ electrolyte, with an available discharge capacity of only $50 \mathrm{mAh} \mathrm{g}^{-1}$ after 50 cycles while a fast capacity stabilization around $240 \mathrm{mAh} \mathrm{g}^{-1}$ over at least 50 cycles is observed using a hybrid electrolyte (Fig. $7 \mathrm{~b}$ and $\mathrm{S} 4)$.

The present capacities compete also well with those reported for $\alpha-\mathrm{V}_{2} \mathrm{O}_{5}$ in binary $\mathrm{Zn}\left(\mathrm{CF}_{3} \mathrm{SO}_{3}\right)_{2}$-LiTFSI "water in salt" electrolyte in the wider $1.6 \mathrm{~V}-0.3 \mathrm{~V}$ voltage window [23]. A detailed comparison of $\gamma^{\prime}-\mathrm{V}_{2} \mathrm{O}_{5}$ cycling behaviour with $\alpha-\mathrm{V}_{2} \mathrm{O}_{5}$ properties is a difficult task. Indeed, the latter has been mainly investigated in $\mathrm{Zn}\left(\mathrm{CF}_{3} \mathrm{SO}_{3}\right)_{2}$ or $\mathrm{ZnSO}_{4}$ aqueous electrolytes, in various and larger cycling limits, using different electrode technologies and material morphologies, which may explain that scattered capacity values and occasionally contradictory data can be found in the range 200-400 mAh g ${ }^{-1}[24-26,28,29]$. For instance a comparable capacity of $240 \mathrm{mAh} \mathrm{g}^{-1}$ is reported in $3 \mathrm{M} \mathrm{ZnSO}_{4}$ in the wide $1.4 \mathrm{~V}-0.4 \mathrm{~V}$ potential window [26] while higher values of $300-400 \mathrm{mAh} \mathrm{g}^{-1}$ are achieved in the $1.6 \mathrm{~V}-0.2 / 0.5 \mathrm{~V}$ potential range using porous nanofibers [28], ball-milled [25] and $\alpha-\mathrm{V}_{2} \mathrm{O}_{5}$ microspheres [24]. Outstanding values of 400-500 mAh g ${ }^{-1}$ can be reached with ALD-deposited $\mathrm{V}_{2} \mathrm{O}_{5}$ layers on carbon paper but with a mass loading limited to $0.1 \mathrm{mg} \mathrm{cm}^{-2}$ [27].

To understand the peculiar electrochemical storage mechanism underlined by the discharge-charge profiles changes, we have carried out a structural study by XRD and Raman spectroscopy to provide information on the nature of the electroformed phases upon cycling of $\gamma^{\prime}-\mathrm{V}_{2} \mathrm{O}_{5}$ in the $1.6 \mathrm{~V}-0.7 \mathrm{~V}$ range. As shown in Fig. S7, the $\gamma$-type structure of the initial host lattice is kept on first discharge at $0.7 \mathrm{~V}$. The shift toward 
lower $2 \theta$ of the $00 l$ reflections (Fig. S7a) for the electrode discharged at $0.7 \mathrm{~V}$ reveals once again an expanded $c$ interlayer parameter $(10.67 \AA$ vs. $10.03 \AA$ for the initial material). The Raman spectrum of the discharged electrode displays also the characteristic bands of the lithiated $\gamma-\mathrm{LiV}_{2} \mathrm{O}_{5}$ structure (Fig. S7b). After one cycle, the initial structure of $\gamma^{\prime}-\mathrm{V}_{2} \mathrm{O}_{5}$ is completely restored, both at the long range (Fig. S7a) and at the scale of chemical bond (Fig. S7b). Furthermore, no extra peak or band related to the presence of another phase is detected. Such observations are consistent with the high electrochemical reversibility exhibited by the first cycle.

However, upon successive cycling tests, both XRD patterns and Raman analysis indicate the occurrence of an increasing disordering process and suggest a deep structural rearrangement upon cycling (Fig. 8) in line with the change observed in the cycling curves profiles (Fig. 7a and S4). Indeed, the XRD patterns (Fig. 8a) and Raman spectra (Fig. 8b) of discharged electrodes show a huge peak intensity decrease and Raman bands broadening with increasing cycling. This phenomenon takes place rapidly as only the $002,102,101,301,112$ reflection lines of $\gamma-\mathrm{Li}_{x} \mathrm{~V}_{2} \mathrm{O}_{5}$ are still visible for the $6^{\text {th }}$ discharge (Fig. 8a) whereas none of them can be detected for the $50^{\text {th }}$ discharge. However, the presence of a new diffraction peak at $14.23^{\circ}$ after 50 cycles (indicated by a cross in Fig. 8a) points to the formation of a new ill-crystallized phase that could correspond to trigonal $\mathrm{Zn}_{3} \mathrm{~V}_{2} \mathrm{O}_{7}(\mathrm{OH})_{2} .2 \mathrm{H}_{2} \mathrm{O}$ pyrovanadate ( $\mathrm{ZVO}$, space group $P \overline{3} m 1$, JCPDS 50-0570) [44,45]. Similar to $\mathrm{V}_{2} \mathrm{O}_{5}$, ZVO phase exhibits a layered structure built of zinc oxide layers separated by $\mathrm{V}-\mathrm{O}-\mathrm{V}$ pillars $\left(\mathrm{V}_{2} \mathrm{O}_{7}^{4-}\right.$ groups $)$, the water molecules randomly filling the large cavities $[44,45]$. The characteristic peak at $14.23^{\circ}$ observed for the $50^{\text {th }}$ discharge would then correspond to the most intense 001 
reflection of ZVO, giving an interlayer $c$ parameter of $7.3 \AA$, in good accord with the values reported in previous studies [16,44-46].
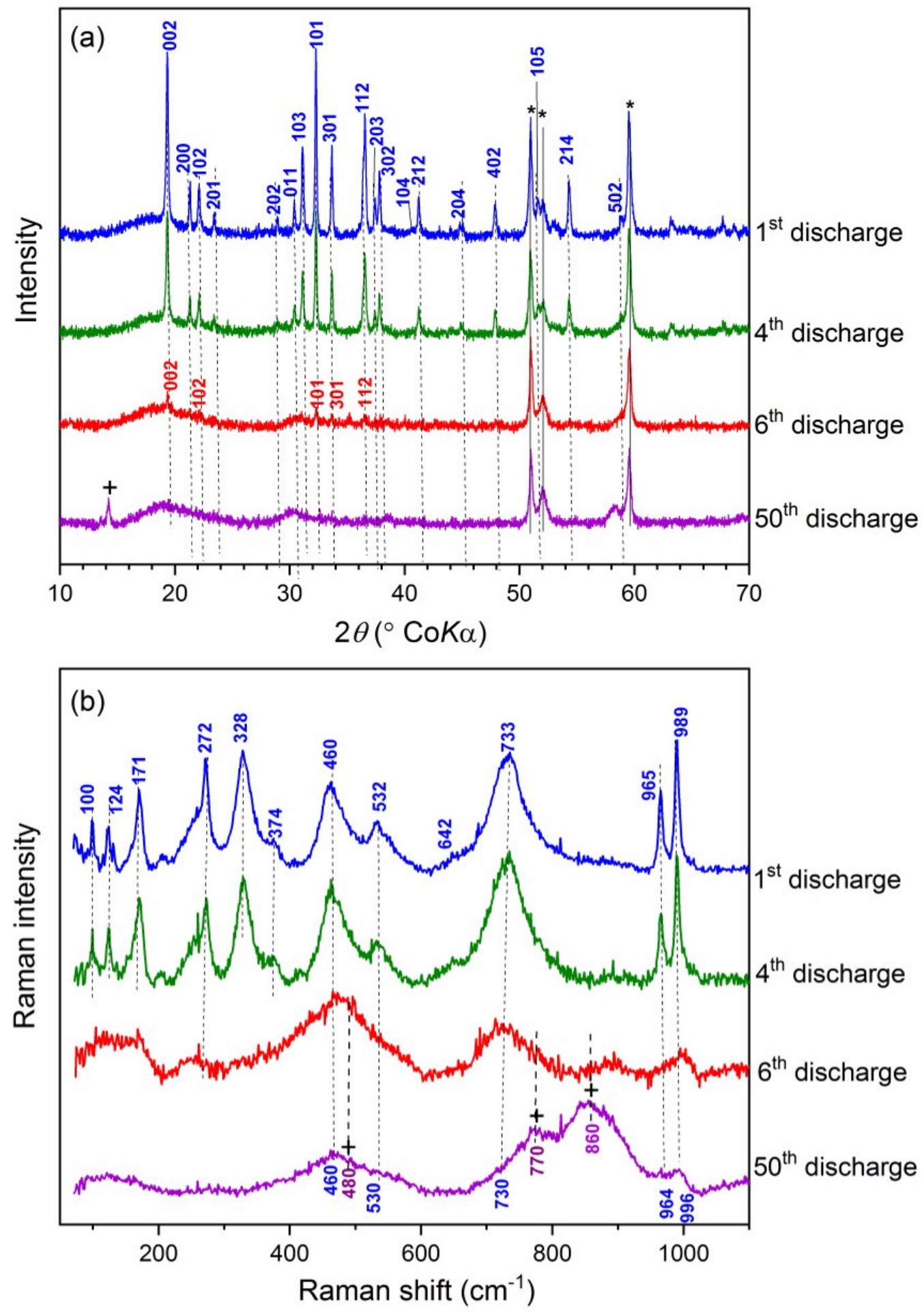

Fig. 8. (a) XRD patterns and (b) Raman spectra of $\gamma^{\prime}-\mathrm{V}_{2} \mathrm{O}_{5}$ discharged electrodes upon cycling. *: sample holder (stainless steel) reflections. +: new phase. $1 \mathrm{C}$ rate. $1.6 \mathrm{~V}$ $0.7 \mathrm{~V}$ voltage window. 
The Raman spectra of discharged electrodes also point to a significant amorphization process with cycling (Fig. 8b). While the typical fingerprint of $\gamma$ $\mathrm{LiV}_{2} \mathrm{O}_{5}$ is nicely distinguished for the $4^{\text {th }}$ discharge, a low intensity spectrum is displayed for the $6^{\text {th }}$ discharge, with broad features centered at 460, 530, 730 and 996 $\mathrm{cm}^{-1}$ indicating the presence of disordered $\gamma-\mathrm{LiV}_{2} \mathrm{O}_{5}$. For the $50^{\text {th }}$ discharge, the Raman spectrum still points to the presence $\gamma-\mathrm{LiV}_{2} \mathrm{O}_{5}$ (characteristic peaks at 460,964 and $996 \mathrm{~cm}^{-1}$ indicated in blue color), however coexisting with a new phase giving well visible bands at 770 and $860 \mathrm{~cm}^{-1}$. Such phase is likely to correspond to ZVO, characterized by Raman modes at 482, 791 and $876 \mathrm{~cm}^{-1}$ [46]. Hence, the bands observed at 770 and $860 \mathrm{~cm}^{-1}$ after 50 cycles (see crosses in Fig. $8 \mathrm{~b}$ ) are likely to correspond to the most intense $\mathrm{V}-\mathrm{O}$ stretching vibrations localized in $\mathrm{VO}_{4}$ and $\mathrm{VO}_{3}$ polyhedra in ZVO. The lower intensity $\mathrm{Zn}-\mathrm{O}$ vibration expected at $482 \mathrm{~cm}^{-1}$ is barely visible in the wide intense $460 \mathrm{~cm}^{-1}$ broad feature of $\mathrm{Ag}$ symmetry assigned to the stretching $v\left(\mathrm{~V}_{\mathrm{b}}-\mathrm{O}_{3}\right)$ mode localized within the $\mathrm{V}_{\mathrm{a}}-\mathrm{O}_{3}-\mathrm{V}_{\mathrm{b}}$ bridges in $\gamma-\mathrm{Li}_{\mathrm{x}} \mathrm{V}_{2} \mathrm{O}_{5}$ [43].

The increasing disordering process upon cycling is also observable on the charged electrodes. Indeed, the typical $h k l$ reflections of $\gamma^{\prime}-\mathrm{V}_{2} \mathrm{O}_{5}$ have practically disappeared after 6 cycles and are no more discernable after 50 cycles (Fig. S8a) while the occurrence of electroformed ZVO manifests itself again through the observation of a 001 reflection at $14.4^{\circ}$. At the level of the chemical bond, the well-defined Raman bands of $\gamma^{\prime}-\mathrm{V}_{2} \mathrm{O}_{5}$ merge into broad bands after 6 cycles, located at ca. 150, 300, 750 and $1000 \mathrm{~cm}^{-1}$ (Fig. S8b) while new components at 480 and $770 \mathrm{~cm}^{-1}$ (indicated by crosses) arise from cycle 6 , revealing the presence of ZVO phase coexisting with disordered $\gamma^{\prime}-\mathrm{V}_{2} \mathrm{O}_{5}$.

This electrochemical and structural study suggests deep structural changes take place upon cycling $\gamma^{\prime}-\mathrm{V}_{2} \mathrm{O}_{5}$ in the $1.6 \mathrm{~V}-0.7 \mathrm{~V}$ voltage range. While an exclusive $\mathrm{Li}$ 
insertion process is clearly demonstrated when the discharge is limited to $1 \mathrm{~V}$, another mechanism responsible for a fast disordering process and involving $\mathrm{Zn}$ participation is observed in the lower $1 \mathrm{~V}-0.7 \mathrm{~V}$ voltage range. XRD and Raman analysis both converge toward the formation of $\mathrm{ZVO}$ as new electroactive phase responsible for the capacity gain, the high capacity and the excellent cyclability highlighted in this work. This gradual phase transformation from $\gamma^{\prime}-\mathrm{V}_{2} \mathrm{O}_{5}$ to $\mathrm{ZVO}$ is probably promoted by a chemical reaction between the positive electrode and the aqueous hybrid electrolyte according to Eq. (1) and Eq. (2) [27]:

$$
\begin{array}{r}
\mathrm{V}_{2} \mathrm{O}_{5}+3 \mathrm{H}_{2} \mathrm{O} \leftrightarrows 2 \mathrm{VO}_{2}(\mathrm{OH})_{2}^{-}+2 \mathrm{H}^{+} \\
2 \mathrm{VO}_{2}(\mathrm{OH})_{2}{ }^{-}+3 \mathrm{Zn}^{2+}+3 \mathrm{H}_{2} \mathrm{O} \leftrightarrows \mathrm{Zn}_{3} \mathrm{~V}_{2} \mathrm{O}_{7}(\mathrm{OH})_{2} \cdot 2 \mathrm{H}_{2} \mathrm{O}+4 \mathrm{H}^{+}
\end{array}
$$

Hence, the mechanism involved during discharge-charge in the present binary electrolyte is illustrated in Eq. (3) and Eq. (4):

In the $1.6 \mathrm{~V}-1 \mathrm{~V}$ voltage range $(x<1)$ :

$$
\gamma^{\prime}-\mathrm{V}_{2} \mathrm{O}_{5}+x \mathrm{e}^{-}+x \mathrm{Li}^{+} \leftrightarrows \gamma-\mathrm{Li}_{x} \mathrm{~V}_{2} \mathrm{O}_{5}
$$

In the $1 \mathrm{~V}-0.7 \mathrm{~V}$ voltage range (after activation):

$$
\mathrm{ZVO}+(x+2 y) \mathrm{e}^{-}+x \mathrm{Li}^{+}+y \mathrm{Zn}^{2+} \leftrightarrows \mathrm{Li}_{x} \mathrm{Zn}_{y} \mathrm{ZVO}
$$

Previous works have reported ZVO as promising intercalation cathode for aqueous ZIB [16] and non-aqueous Li-ion battery [46]. Such findings are ascribed to the open framework with large interlayer spacing of ZVO $(0.74 \mathrm{~nm} v s 0.43 \mathrm{~nm}$ for hydrated ionic radius of $\mathrm{Zn}^{2+}$ ), providing an ideal pathway for guest species intercalation.

Even when all structural data on $\mathrm{V}_{2} \mathrm{O}_{5}$ derived electrodes deal with cycling properties obtained in wider voltage ranges using a lower cutoff voltage $(0.2 \mathrm{~V}-0.4$ V) and only a $\mathrm{Zn}$ salt $\left(3 \mathrm{M} \mathrm{ZnSO} 4\right.$ or $\left.\mathrm{Zn}\left(\mathrm{CF}_{3} \mathrm{SO}_{3}\right)_{2}\right)$, some common features exist with the present study. Indeed, a phase transformation is often reported upon successive discharge-charge cycles involving the hydrated layered phases $\mathrm{H}_{2} \mathrm{~V}_{3} \mathrm{O}_{8}$ [26] or 
$\mathrm{Zn}_{x} \mathrm{~V}_{2} \mathrm{O}_{5} \quad n \mathrm{H}_{2} \mathrm{O}$ [25] while other studies indicate the predominant role of $\mathrm{Zn}_{3} \mathrm{~V}_{2} \mathrm{O}_{7}(\mathrm{OH})_{2} .2 \mathrm{H}_{2} \mathrm{O}[27,28]$. The present structural analysis clearly demonstrates a fast transformation of $\gamma^{\prime}-\mathrm{V}_{2} \mathrm{O}_{5}$ from the first cycle. XRD and Raman data show a more complex mechanism than in pure $\mathrm{Zn}$ based electrolytes since $\mathrm{Li}$ ions can still participate to the electrochemical process of layered ZVO phases whatever their composition. However, the active material obtained after capacity stabilization is made of disordered $\gamma^{\prime}-\mathrm{V}_{2} \mathrm{O}_{5}$ and ZVO. It can be argued that longer cycling experiments would allow a complete conversion of the initial crystalline $\gamma^{\prime}-\mathrm{V}_{2} \mathrm{O}_{5}$ phase into ZVO.

Additional supporting evidence to the phase transformation is provided by EDX measurements performed for electrodes discharged to $0.7 \mathrm{~V}\left(1^{\text {st }}, 4^{\text {th }}, 6^{\text {th }}\right.$ and $50^{\text {th }}$ discharge). Table 1 shows that the discharged product continuously enriches itself with $\mathrm{Zn}$ ions with cycling, as revealed by the significant increase of the $\mathrm{Zn} / \mathrm{V}$ ratio. Such a finding supports a phase transformation from $\gamma^{\prime}-\mathrm{V}_{2} \mathrm{O}_{5}$ to $\mathrm{ZVO}$, as recently evidenced in $3 \mathrm{M} \mathrm{Zn}\left(\mathrm{CF}_{3} \mathrm{SO}_{3}\right)_{2}$ electrolyte for Atomic Layer Deposited derived $\alpha-\mathrm{V}_{2} \mathrm{O}_{5}$ [27] and $\alpha-\mathrm{V}_{2} \mathrm{O}_{5}$ nanofibers [28]. The maximum $\mathrm{Zn} / \mathrm{V}$ value of 0.62 associated to a faradaic yield of $1.2 \mathrm{e}^{-} / \mathrm{mol}$ of $\mathrm{V}_{2} \mathrm{O}_{5}$ discards a pure $\mathrm{Zn}$ insertion reaction leading to the $\mathrm{Zn}_{x} \mathrm{~V}_{2} \mathrm{O}_{5}$ bronze. Moreover, this value does not meet either the expected $\mathrm{Zn} / \mathrm{V}$ ratio of 1.5 in $\mathrm{ZVO}$, which can be understood assuming the coexistence of disordered $\gamma^{\prime}-\mathrm{V}_{2} \mathrm{O}_{5}$ with ZVO in the electrodes, in which Li ions can still be reversibly inserted.

Table 1. $\mathrm{Zn} / \mathrm{V}$ ratios determined from EDX in discharged $\gamma^{\prime}-\mathrm{V}_{2} \mathrm{O}_{5}$ electrodes at $0.7 \mathrm{~V}$. Cycle rate $1 \mathrm{C}$.

\begin{tabular}{ll}
\hline Discharge number & $\mathrm{Zn} / \mathrm{V}$ \\
\hline 1 & 0.16 \\
4 & 0.27 \\
6 & 0.51 \\
50 & 0.62 \\
\hline
\end{tabular}




\section{Conclusions}

In this work, we present the layered-puckered $\gamma^{\prime}-\mathrm{V}_{2} \mathrm{O}_{5}$ as a prospective cathode for zinc-ion batteries in a binary $3.5 \mathrm{M} \mathrm{ZnSO}_{4}+2.5 \mathrm{M} \mathrm{Li}_{2} \mathrm{SO}_{4}$ electrolyte. After an activation process of a few cycles, high and stable capacities of $240 \mathrm{mAh} \mathrm{g}^{-1}$ and 190 $\mathrm{mAh} \mathrm{g}^{-1}$ are achieved in the $1.6 \mathrm{~V}-0.7 \mathrm{~V}$ potential window at $\mathrm{C} / 5$ and $1 \mathrm{C}$ rate, respectively. These capacities outperform those reported for the conventional $\alpha-\mathrm{V}_{2} \mathrm{O}_{5}$ oxide in the same electrolyte. The detailed structural evolution during first dischargecharge and subsequent cycling in two different voltage ranges $(1.6 \mathrm{~V}-1 \mathrm{~V}$ and $1.6 \mathrm{~V}$ - 0.7 V) is investigated using XRD and Raman spectroscopy. We show the occurrence of selective lithium intercalation in the $1.6 \mathrm{~V}-1 \mathrm{~V}$ voltage window, with a reversible exchange of $0.8 \mathrm{Li}^{+}$in $\gamma^{\prime}-\mathrm{V}_{2} \mathrm{O}_{5}$ inducing the same structural response as the one reported in lithiated organic electrolyte while a concurrent reaction involving zinc ions takes place concomitantly in the extended $1.6 \mathrm{~V}-0.7 \mathrm{~V}$ range.

A gradual phase transformation from $\gamma^{\prime}-\mathrm{V}_{2} \mathrm{O}_{5}$ to zinc pyrovanadate $\mathrm{Zn}_{3} \mathrm{~V}_{2} \mathrm{O}_{7}(\mathrm{OH})_{2} .2 \mathrm{H}_{2} \mathrm{O}$ during cycling is strongly supported by XRD, Raman and EDX analysis. This work highlights the benefit provided by the peculiar layered-puckered $\gamma^{\prime}-\mathrm{V}_{2} \mathrm{O}_{5}$ against conventional $\alpha-\mathrm{V}_{2} \mathrm{O}_{5}$ with a huge improvement of capacity of 240 $\mathrm{mAh} \mathrm{g}^{-1}$ vs $80 \mathrm{mAh} \mathrm{g}^{-1}$ at $\mathrm{C} / 5$ in the same voltage window. Further optimization of cycling properties are under investigation by lowering the cut-off voltage to $0.3 \mathrm{~V}$.

\section{Declaration of competing interests}

The authors declare that they have no known competing financial interests or personal relationships that could have appeared to influence the work reported in this paper. 


\section{Acknowledgments}

One of the authors wishes to thank the Ministry of Education and Science of Kazakhstan (grant number AP05136016-ZRABS), French Embassy in Astana, Kazakhstan and Campus France for financial support. All the authors thank Dr. Nicolas Emery (ICMPE-CNRS) for assistance in refinement of XRD data.

\section{References}

[1] D. Kundu, B.D. Adams, V. Duffort, S.H. Vajargah, L.F. Nazar, Nat. Energy 1 (2016) 16119.

[2] H. Pan, Y. Shao, P. Yan, Y. Cheng, K.S. Han, Z. Nie, C. Wang, J. Yang, X. Li, P. Bhattacharya, Nat. Energy 1 (2016) 16039.

[3] F. Wan, L. Zhang, X. Dai, X.Wang, Z. Niu, J. Chen, Nat. Commun. 9 (2018) 1656. [4] A. Konarov, N. Voronina, J.H. Jo, Z. Bakenov, Y.-K. Sun, S.-T. Myung, ACS Energy Lett. 3 (2018) 2620-2640.

[5] J. Ming, J. Guo, C. Xia, W. Wang, H.N. Alshareef, Mater. Sci. Eng.: R: Reports 135 (2019) 58-84.

[6] G. Fang, J. Zhou, A. Pan, S. Liang, ACS Energy Lett. 3 (2018) 2480-2501.

[7] M. Yan, P. He, Y. Chen, S. Wang, Q. Wei, K. Zhao, X. Xu, Q. An, Y. Shuang, Y. Shao, Adv. Mater. 30 (2018) 1703725.

[8] Y. Li, P. Xu, J. Jiang, J. Yao, B. Huang, J. Yang, Mater. Today Commun. (2020) 101849.

[9] P. He, Y. Quan, X. Xu, M. Yan, W. Yang, Q. An, L. He, L. Mai, Small 13 (2017) 1702551.

[10] T. Wei, Q. Li, G. Yang, C. Wang, Electrochim. Acta 287 (2018) 60-67.

[11] F. Ming, H. Liang, Y. Lei, S. Kandambeth, M. Eddaoudi, H.N. Alshareef, ACS Energy Lett. 3 (2018) 2602-2609.

[12] B. Sambandam, V. Soundharrajan, S. Kim, M.H. Alfaruqi, J. Jo, S. Kim, V. Mathew, Y.-K Sun, J. Kim, J. Mater. Chem. A 6 (2018) 15530-15539.

[13] C. Xia, J. Guo, P. Li, X. Zhang, H.N. Alshareef, Angew. Chemie Int. Ed. 57 (2018) 3943-3948.

[14] V. Soundharrajan, B. Sambandam, S. Kim, M.H. Alfaruqi, D.Y. Putro, J. Jo, S. Kim, V. Mathew, Y.-K. Sun, J. Kim, Nano Lett. 18 (2018) 2402-2410.

[15] Z. Peng, Q. Wei, S. Tan, P. He, W. Luo, Q. An, L. Mai, Chem. Commun. 54 (2018) 4041-4044.

[16] C. Xia, J. Guo, Y. Lei, H. Liang, C. Zhao, H.N. Alshareef, Adv. Mater. 30 (2017) 1705580.

[17] J. Li, K. McColl, X. Lu, S. Sathasivam, H. Dong, L. Kang, Z. Li, S. Zhao, A.G. Kafizas, R. Wang, D.J.L. Brett, P.R. Shearing, F. Corà, G. He, C. J. Carmalt, I.P. Parkin, Adv. Energy Mater. 10 (2020) 2000058.

[18] T. Wei, Q. Li, G. Yang, C. Wang, J. Mater. Chem. A 6 (2018) 8006-8012.

[19] B. Sambandam, V. Soundharrajan, S. Kim, M.H. Alfaruqi, J. Jo, S. Kim, V. Mathew, Y.-K Sun, J. Kim, J. Mater. Chem. A 6 (2018) 3850-3856.

[20] G. Yang, T. Wei, C. Wang, ACS Appl. Mater. Interfaces 10 (2018) 35079-35089. [21] B. Tang, G. Fang, J. Zhou, L. Wang, Y. Lei, C. Wang, T. Lin, Y. Tang, S. Liang, Nano Energy 51 (2018) 579-587. 
[22] M.H. Alfaruqi, V. Mathew, J. Song, S. Kim, S. Islam, D.T. Pham, J. Jo, S. Kim, J.P. Baboo, Z. Xiu, Chem. Mater. 29 (2017) 1684-1694.

[23] P. Hu, M. Yan, T. Zhu, X. Wang, X. Wei, J. Li, L. Zhou, Z. Li, L. Chen, L. Mai, ACS Appl. Mater. Interfaces 9 (2017) 42717-42722.

[24] P. Hu, T. Zhu, J. Ma, C. Cai, G. Hu, X. Wang, Z. Liu, L. Zhou, L. Mai, Chem. Commun. 55 (2019) 8486-8489.

[25] N. Zhang, Y. Dong, M. Jia, X. Bian, Y. Wang, M. Qiu, J. Xu, Y. Liu, L. Jiao, F. Cheng, ACS Energy Lett. 3 (2018) 1366-1372.

[26] J. Zhou, L. Shan, Z. Wu, X. Guo, G. Fang, S. Liang, Chem. Commun. 54 (2018) 4457-4460.

[27] Y. Lu, T. Zhu, W. van den Bergh, M. Stefik, K. Huang, Angew. Chem. Int. Ed. 59 (2020) 17004-17011.

[28] X. Chen, L. Wang, H. Li, F. Cheng, J. Chen, J. Energy Chem. 38 (2019) 20-25.

[29] W. Zhou , J. Chen, M. Chen, X. Xu, Q.Tian, J. Xu, C.P. Wong, RSC Adv. 9 (2019) 30556-30564.

[30] J.Yan, J. Wang, H. Liu, Z. Bakenov, D. Gosselink, P. Chen, J. Power Sources 216 (2012) 222-226.

[31] N. Yesibolati, N. Umirov, A. Koishybaya, M. Omarova, I. Kurmanbayeva, Y. Zhang, Y. Zhao, Z. Bakenov, Electrochim. Acta 152 (2014) 505-511.

[32] G. Yuan, J. Bai, T.N.L. Doan, P. Chen, Mater. Lett. 158 (2015) 248-251.

[33] H.B. Zhao, C.J. Hu, H.W. Cheng, J.H. Fang, Y.P. Xie, W.Y. Fang, T.N.L. Doan, T.K.A. Hoang, J.Q. Xu, P. Chen, Sci. Rep. 6 (2016) 1-10.

[34] Z. Liu, Q. Yang, D. Wang, G. Liang, Y. Zhu, F. Mo, Z. Huang, X. Li, L. Ma, T. Tang, Z. Lu, C. Zhi, Adv. Energy Mater. 9, 1-12 (2019).

[35] F. Wang, Y. Liu, X. Wang, Z. Chang,Y. Wu, R. Holze, ChemElectroChem 2

(2015) 1024-1030.

[36] J. Zhao, Y. Li, X. Peng, S. Dong, J. Ma, G. Cui, L. Chen, Electrochem. commun. (2016) 69, 6-10.

[37] D. Batyrbekuly, S. Cajoly, B. Laïk, J.-P. Pereira-Ramos, N. Emery, Z. Bakenov, R. Baddour-Hadjean, ChemSusChem 13 (2020) 724-731.

[38] R. Baddour-Hadjean, M.B. Smirnov, V.Y. Kazimirov, K.S. Smirnov, J.-P. Pereira-Ramos, J. Raman Spectrosc. 46 (2015) 406-412.

[39] N. Emery, R. Baddour-Hadjean, D. Batyrbekuly, B. Laïk, Z. Bakenov, J.-P. Pereira-Ramos, Chem. Mater. 30 (2018) 5305-5314.

[40] R. Baddour-Hadjean, M. Safrany Renard, J.-P. Pereira-Ramos, Acta Mater. 165 (2019) 183-191.

[41] M. Safrany Renard, N. Emery, R. Baddour-Hadjean, J.-P. Pereira-Ramos, Electrochim. Acta 252 (2017) 4-11.

[42] I. Mjejri, A. Rougier, M. Gaudon, Inorg. Chem. 56 (2017) 1734-1741.

[43] M.B. Smirnov, E.M. Roginskii, V.Y. Kazimirov, K.S. Smirnov, R. BaddourHadjean, J.-P. Pereira-Ramos, V.S. Zhandun, J. Phys. Chem. C 119 (2015) 20801-20809. https://doi.org//10.1021/acs.jpcc.5b05540.

[44] P.Y. Zavalij, F. Zhang, M.S. Whittingham, Acta Cryst. C 53 (1997) 1738-1739.

[45] T. Chirayil, P. Y. Zavalij, M.S. Whittingham, Chem. Mater. 10 (1998) 26292640.

[46] S. Ni, G. Zhou, S. Li, X. Wang, Q. Pan, F. Yang, D. He, Mater. Lett. 63 (2009) 24592461. 


\section{Graphical Abstract}

$\gamma^{\prime}-\mathrm{V}_{2} \mathrm{O}_{5}$, which undergoes a transition toward zinc pyrovanadate (ZVO) below $1 \mathrm{~V}$ during first cycles and dual $\mathrm{Li}^{+} / \mathrm{Zn}^{2+}$ insertion/extraction in the layered hosts thereafter, is a new attractive cathode material for ARZB.

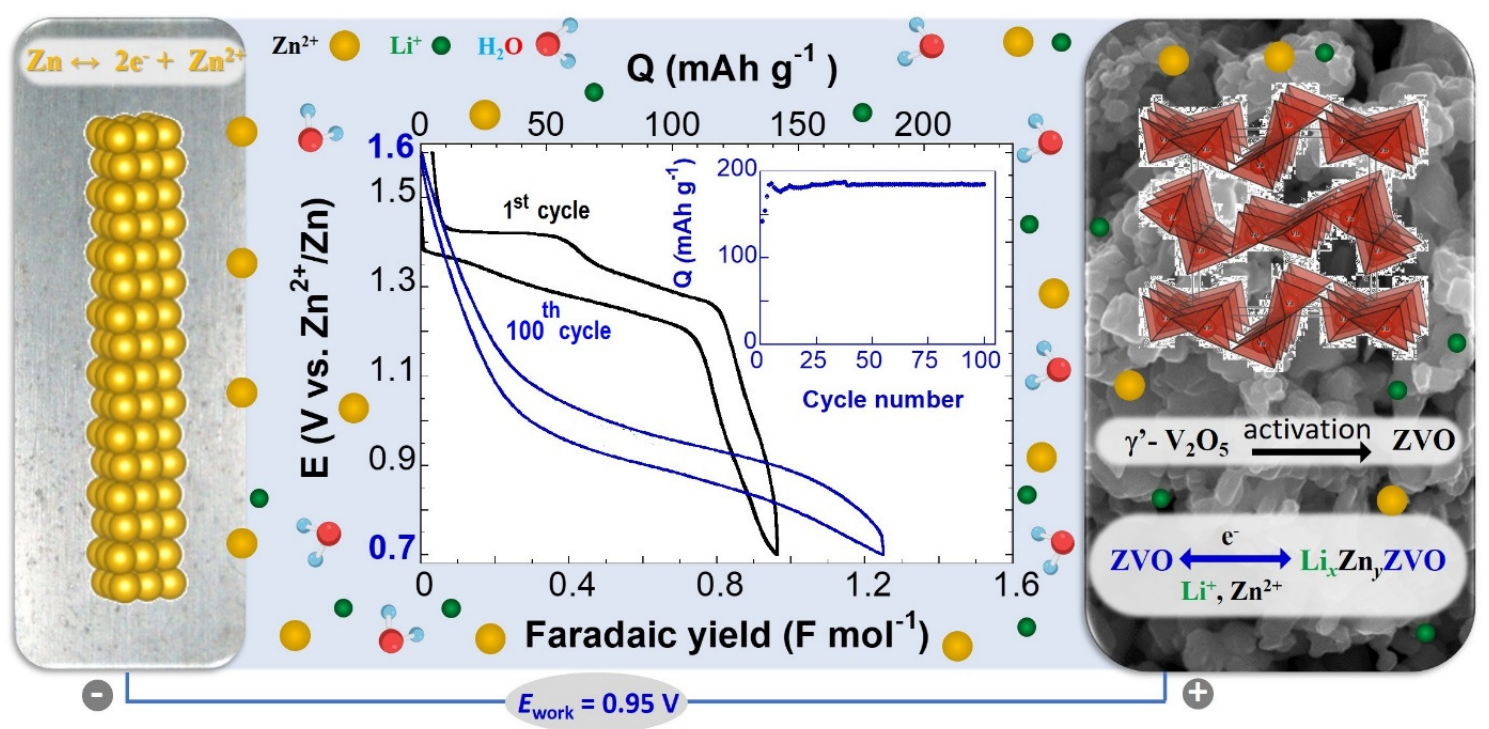




\section{Figure captions}

Figure 1. SEM micrographs of as-prepared $\gamma^{\prime}-\mathrm{V}_{2} \mathrm{O}_{5}$ powder

Figure 2. (a) X-ray diffraction pattern of $\gamma^{\prime}-\mathrm{V}_{2} \mathrm{O}_{5}$ powder. Inset: crystal structure of $\gamma^{\prime}-\mathrm{V}_{2} \mathrm{O}_{5}$ (b) Raman spectrum of $\gamma^{\prime}-\mathrm{V}_{2} \mathrm{O}_{5}$ powder. Inset: projection of the structure of $\gamma^{\prime}-\mathrm{V}_{2} \mathrm{O}_{5}$ along the $b$-crystallographic direction showing all the $\mathrm{V}-\mathrm{O}$ contacts. Dashed lines show $\mathrm{V}$ - O interchain contacts (ladder-step bonds)

Figure 3. (a) Cyclic voltammograms (scanning rate $0.2 \mathrm{mV} \mathrm{s}^{-1}$ ) and (b) First galvanostatic cycles at $\mathrm{C} / 5$ rate of $\gamma^{\prime}-\mathrm{V}_{2} \mathrm{O}_{5}$ (black curves) and $\alpha-\mathrm{V}_{2} \mathrm{O}_{5}$ (red dotted curves)

Figure 4. X-ray diffraction patterns of reduced $\gamma^{\prime}-\mathrm{V}_{2} \mathrm{O}_{5}$ electrodes during the first discharge at $\mathrm{C} / 5$ as a function of the faradaic yield $\mathrm{x}\left(\mathrm{F} \mathrm{mol}^{-1}\right) .0 \leq \mathrm{x} \leq 0.72$. *: sample holder (stainless steel) reflections. 1.6 V - $1 \mathrm{~V}$ voltage window

Figure 5. Evolution of the unit cell parameters $a, b, c$ and unit cell volume of reduced $\gamma^{\prime}-\mathrm{V}_{2} \mathrm{O}_{5}$ electrodes during the first discharge at $\mathrm{C} / 5$ as a function of the faradaic yield $\mathrm{x}\left(\mathrm{F} \mathrm{mol}{ }^{-1}\right) .0 \leq \mathrm{x} \leq 0.72$. Black squares: $\gamma^{\prime}-\mathrm{V}_{2} \mathrm{O}_{5}$; red squares: new phase

Figure 6. Raman spectra of reduced $\gamma^{\prime}-\mathrm{V}_{2} \mathrm{O}_{5}$ electrodes during the first discharge at $\mathrm{C} / 5$ as a function of the faradaic yield $\mathrm{x}\left(\mathrm{F} \mathrm{mol}^{-1}\right) .0 \leq \mathrm{x} \leq 0.72 .1 .6 \mathrm{~V}-1 \mathrm{~V}$ voltage window

Figure 7. Electrochemical performance of $\gamma^{\prime}-\mathrm{V}_{2} \mathrm{O}_{5}$ in the extended $1.6 \mathrm{~V}-0.7 \mathrm{~V}$ voltage window: (a) Discharge-charge cycles at $1 \mathrm{C}$ rate; (b) Evolution of the specific capacity as a function of the number of cycles at $\mathrm{C} / 5$ and $1 \mathrm{C}$ rates; (c) Rate capability study

Figure 8. (a) XRD patterns and (b) Raman spectra of $\gamma^{\prime}-\mathrm{V}_{2} \mathrm{O}_{5}$ discharged electrodes upon cycling. *: sample holder (stainless steel) reflections. + : new phase. 1C rate. $1.6 \mathrm{~V}-0.7 \mathrm{~V}$ voltage window 


\section{Appendix A: Supplementary data}

Figure S1. Rietveld refinement of $\gamma^{\prime}-\mathrm{V}_{2} \mathrm{O}_{5}$ XRD pattern

Figure S2. (a) XRD patterns and (b) Raman spectra of initial $\gamma^{\prime}-\mathrm{V}_{2} \mathrm{O}_{5}$ electrode and after one discharge-charge cycle. $\mathrm{C} / 5$ rate. $1.6 \mathrm{~V}-1 \mathrm{~V}$ voltage window. Stars correspond to the sample holder (stainless steel) reflections

Figure S3. Influence of the $\mathrm{C}$ rate on discharge-charge curves of $\gamma^{\prime}-\mathrm{V}_{2} \mathrm{O}_{5} .1 .6 \mathrm{~V}-1 \mathrm{~V}$ voltage window. $2.5 \mathrm{M} \mathrm{Li}_{2} \mathrm{SO}_{4}-3.5 \mathrm{M} \mathrm{ZnSO}_{4}$ electrolyte

Figure S4. Discharge-charge curves of $\gamma^{\prime}-\mathrm{V}_{2} \mathrm{O}_{5}$ during cycling at $\mathrm{C} / 5$ rate. $1.6 \mathrm{~V}-0.7$ $\mathrm{V}$ voltage window. $2.5 \mathrm{M} \mathrm{Li}_{2} \mathrm{SO}_{4}-3.5 \mathrm{M} \mathrm{ZnSO}_{4}$ electrolyte

Figure S5. Typical discharge-charge curves of $\gamma^{\prime}-\mathrm{V}_{2} \mathrm{O}_{5}$ at different C-rates after 10 activation cycles at $\mathrm{C} / 5.1 .6 \mathrm{~V}-0.7 \mathrm{~V}$ voltage window. $2.5 \mathrm{M} \mathrm{Li}_{2} \mathrm{SO}_{4}-3.5 \mathrm{M} \mathrm{ZnSO} 4$ electrolyte

Figure S6. Discharge-charge curves of $\gamma^{\prime}-\mathrm{V}_{2} \mathrm{O}_{5}$ during cycling at $\mathrm{C} / 5$ rate. $1.6 \mathrm{~V}-$ $0.7 \mathrm{~V}$ voltage window. $3.5 \mathrm{M} \mathrm{ZnSO}_{4}$ electrolyte

Figure S7. (a) XRD patterns and (b) Raman spectra of initial $\gamma^{\prime}-\mathrm{V}_{2} \mathrm{O}_{5}$ electrode, after the first discharge and after the first discharge-charge cycle. Stars correspond to the sample holder (stainless steel) reflections. $1 \mathrm{C}$ rate. $1.6 \mathrm{~V}-0.7 \mathrm{~V}$ voltage window

Figure S8. (a) XRD patterns and (b) Raman spectra of initial $\gamma^{\prime}-\mathrm{V}_{2} \mathrm{O}_{5}$ and after cycle tests. *: sample holder (stainless steel) reflections. +: new phase. $1 \mathrm{C}$ rate. $1.6 \mathrm{~V}-0.7$ $\mathrm{V}$ voltage window 


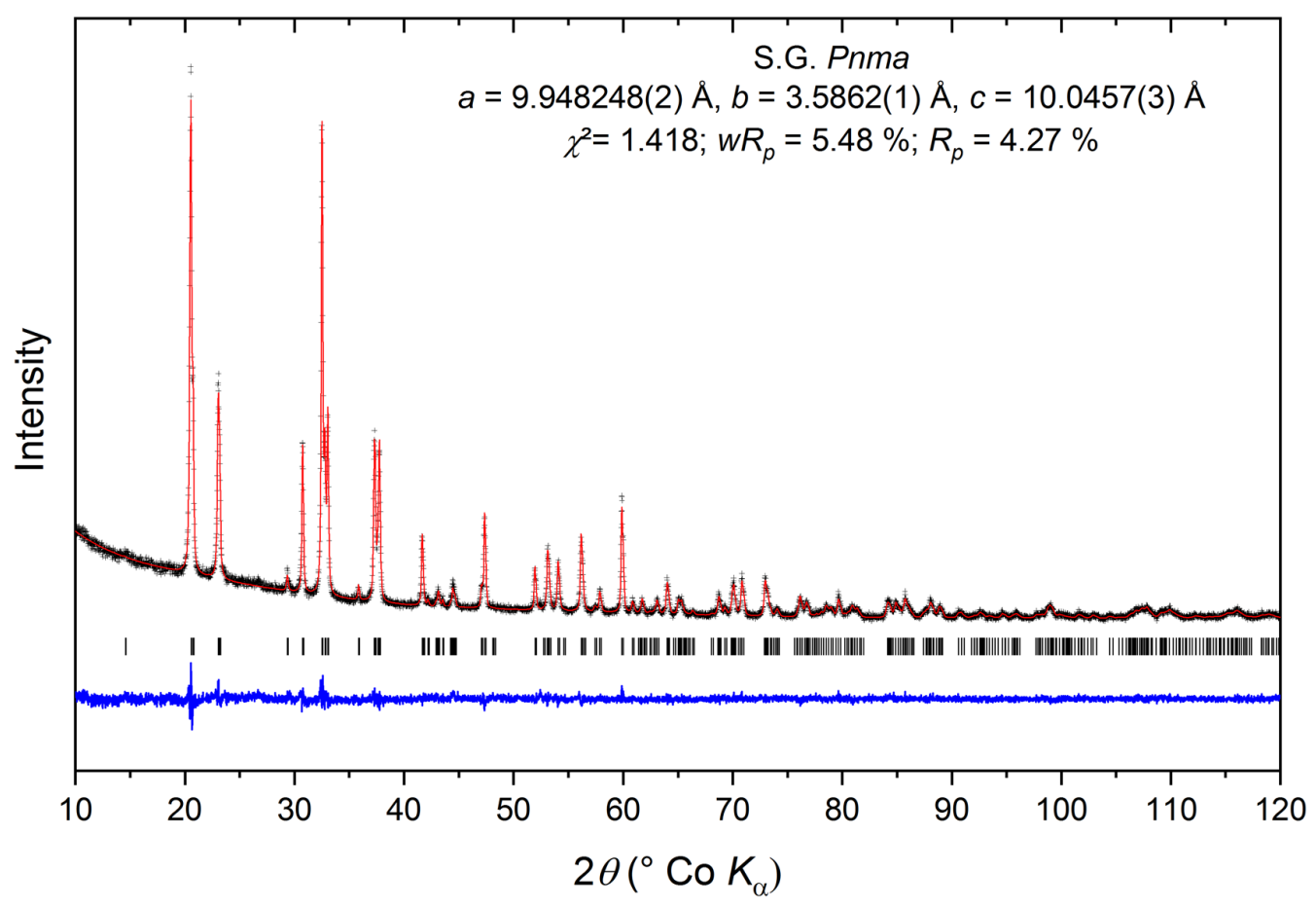

Fig. S1. Rietveld refinement of $\gamma^{\prime}-\mathrm{V}_{2} \mathrm{O}_{5}$ XRD pattern 

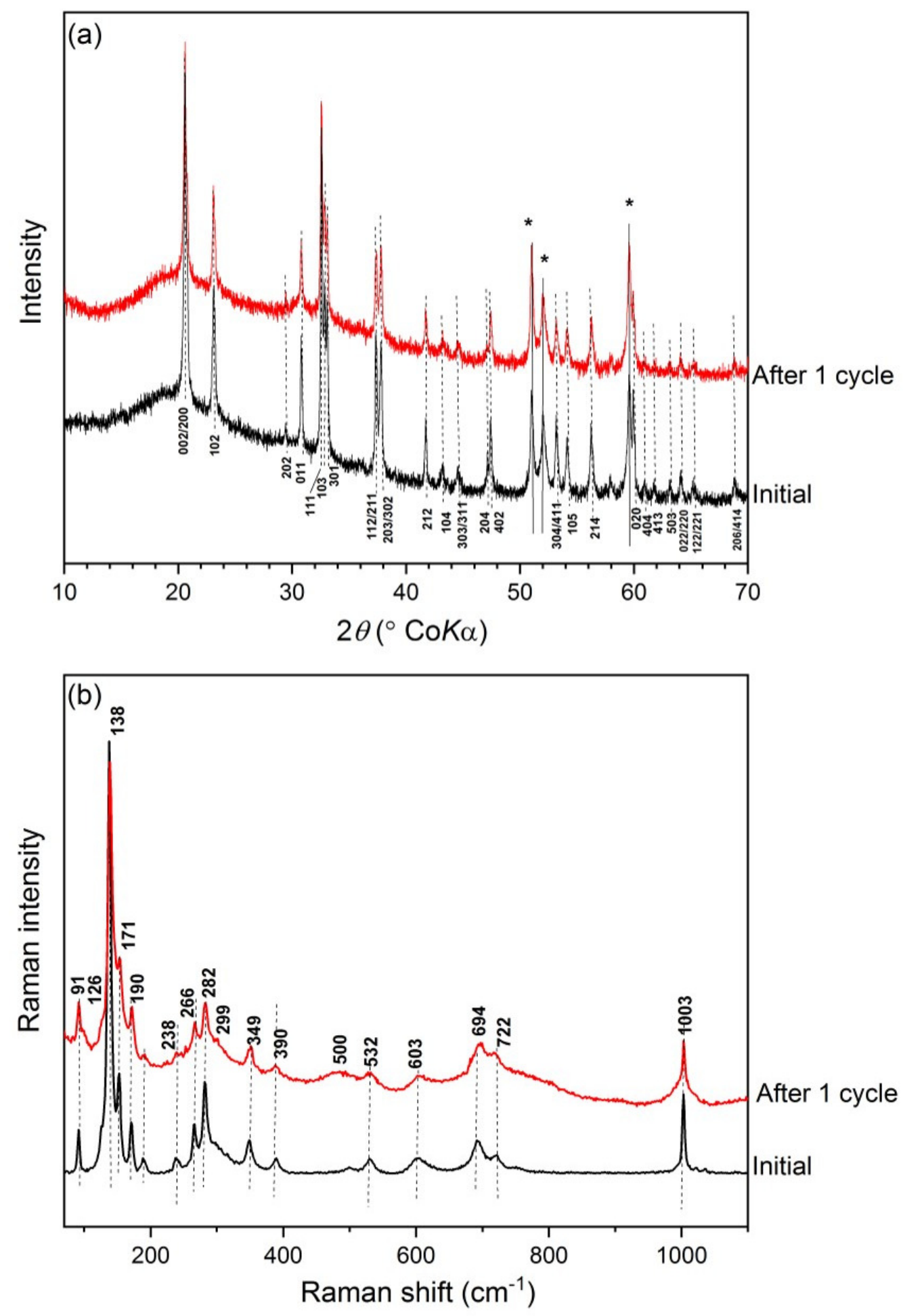

Fig. S2. (a) XRD patterns and (b) Raman spectra of initial $\gamma^{\prime}-\mathrm{V}_{2} \mathrm{O}_{5}$ electrode and after one discharge-charge cycle at $\mathrm{C} / 5$ rate. $1.6 \mathrm{~V}-1 \mathrm{~V}$ voltage window. *: sample holder (stainless steel) reflections 


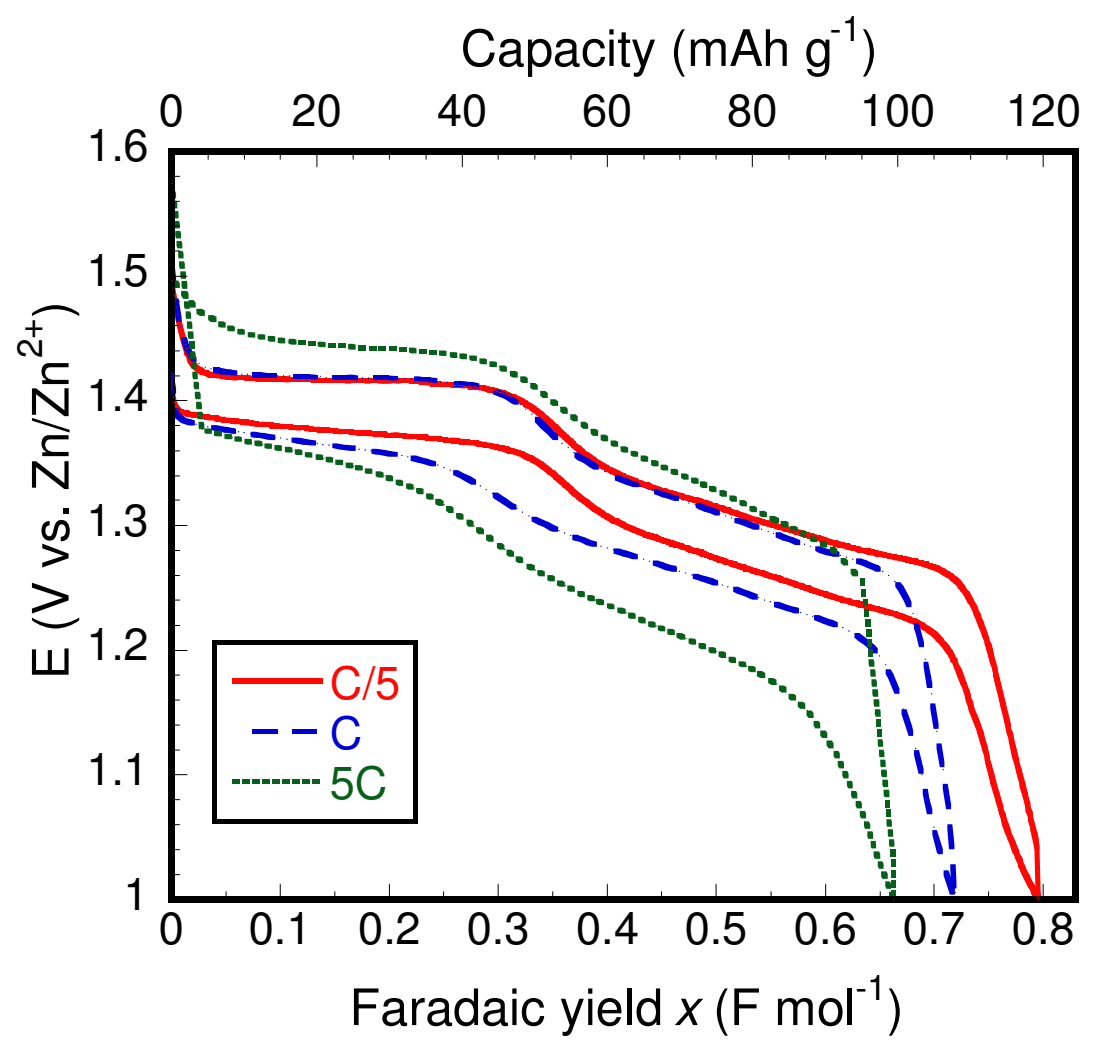

Fig. S3. Influence of the $\mathrm{C}$ rate on discharge-charge curves of $\gamma^{\prime}-\mathrm{V}_{2} \mathrm{O}_{5} .1 .6 \mathrm{~V}-1 \mathrm{~V}$ voltage window. $2.5 \mathrm{M} \mathrm{Li}_{2} \mathrm{SO}_{4}-3.5 \mathrm{M} \mathrm{ZnSO}_{4}$ electrolyte 


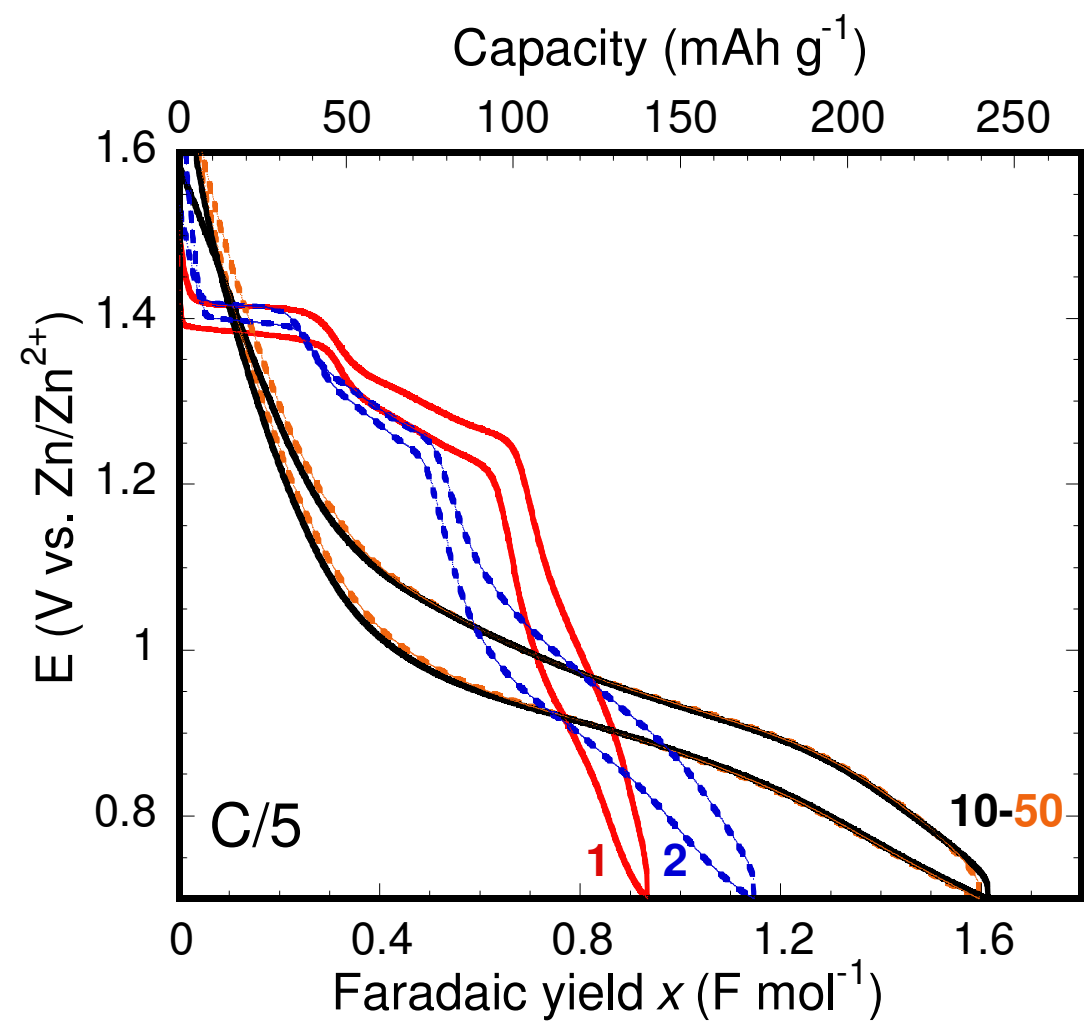

Fig. S4. Discharge-charge curves of $\gamma^{\prime}-\mathrm{V}_{2} \mathrm{O}_{5}$ during cycling at $\mathrm{C} / 5$ rate. $1.6 \mathrm{~V}-0.7 \mathrm{~V}$ voltage window. $2.5 \mathrm{M} \mathrm{Li}_{2} \mathrm{SO}_{4}-3.5 \mathrm{M} \mathrm{ZnSO}_{4}$ electrolyte 


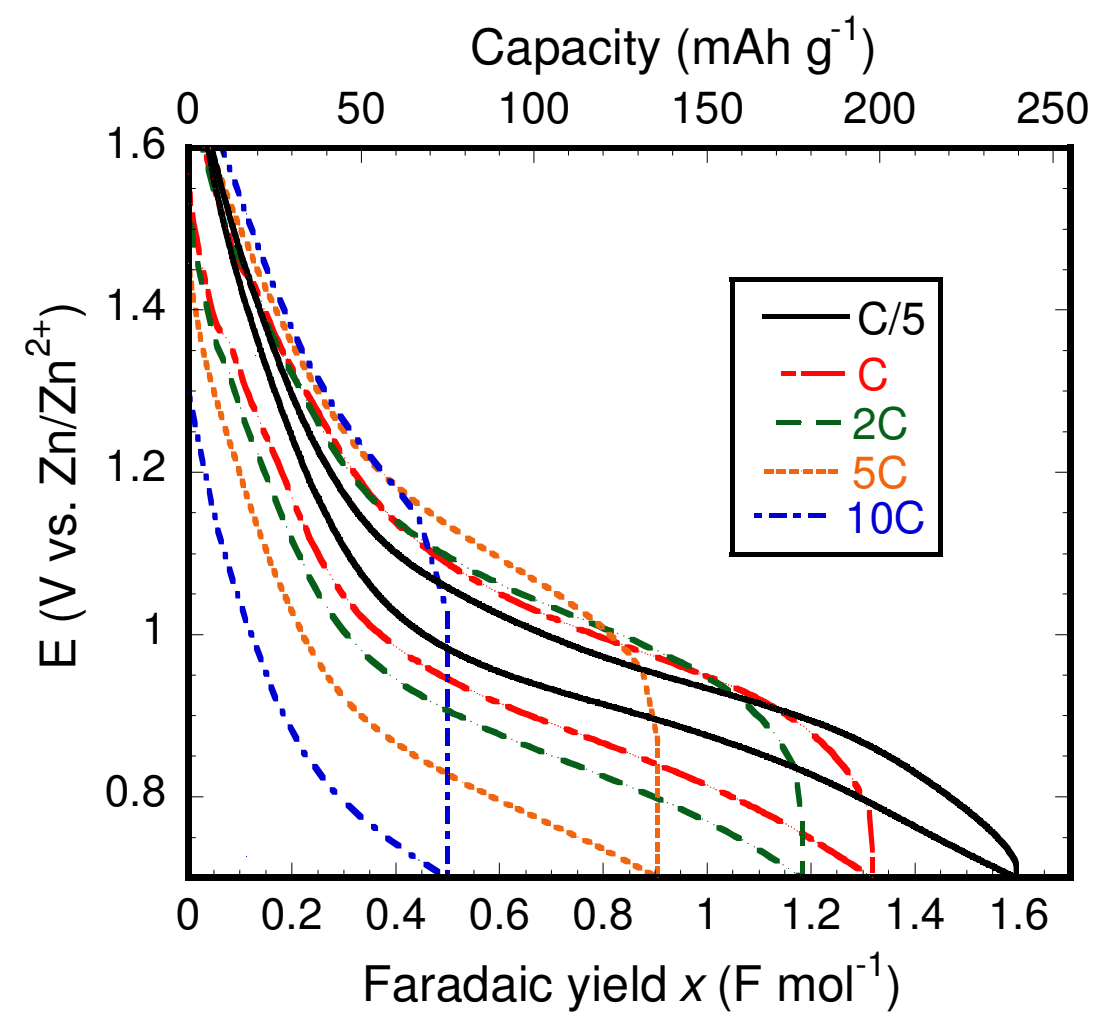

Fig. S5. Typical discharge-charge curves of $\gamma^{\prime}-\mathrm{V}_{2} \mathrm{O}_{5}$ at different C-rates after 10 activation cycles at $\mathrm{C} / 5.1 .6 \mathrm{~V}-0.7 \mathrm{~V}$ voltage window. $2.5 \mathrm{M} \mathrm{Li}_{2} \mathrm{SO}_{4}-3.5 \mathrm{M} \mathrm{ZnSO} 4$ electrolyte 


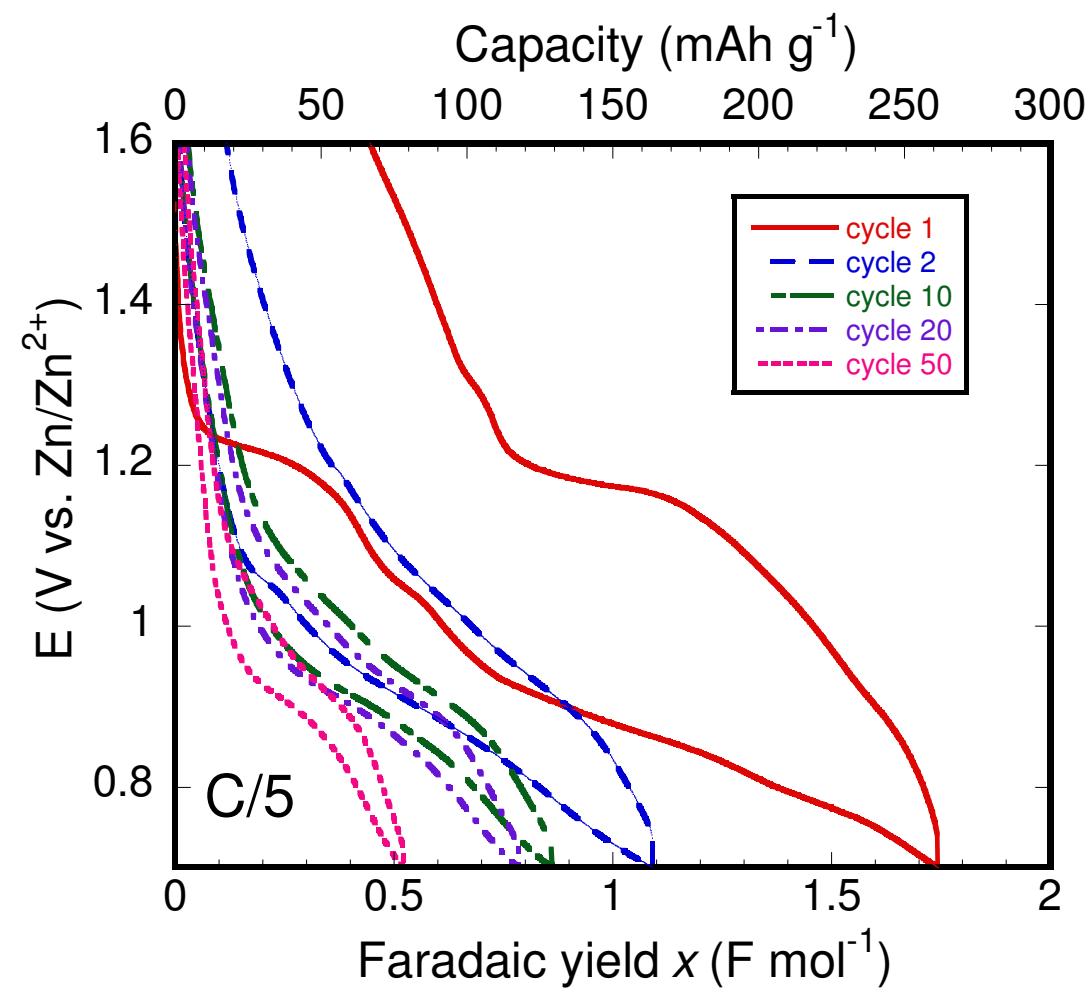

Fig. S6. Discharge-charge curves of $\gamma^{\prime}-\mathrm{V}_{2} \mathrm{O}_{5}$ during cycling at $\mathrm{C} / 5$ rate. $1.6 \mathrm{~V}-0.7 \mathrm{~V}$ voltage window. $3.5 \mathrm{M} \mathrm{ZnSO}_{4}$ electrolyte 

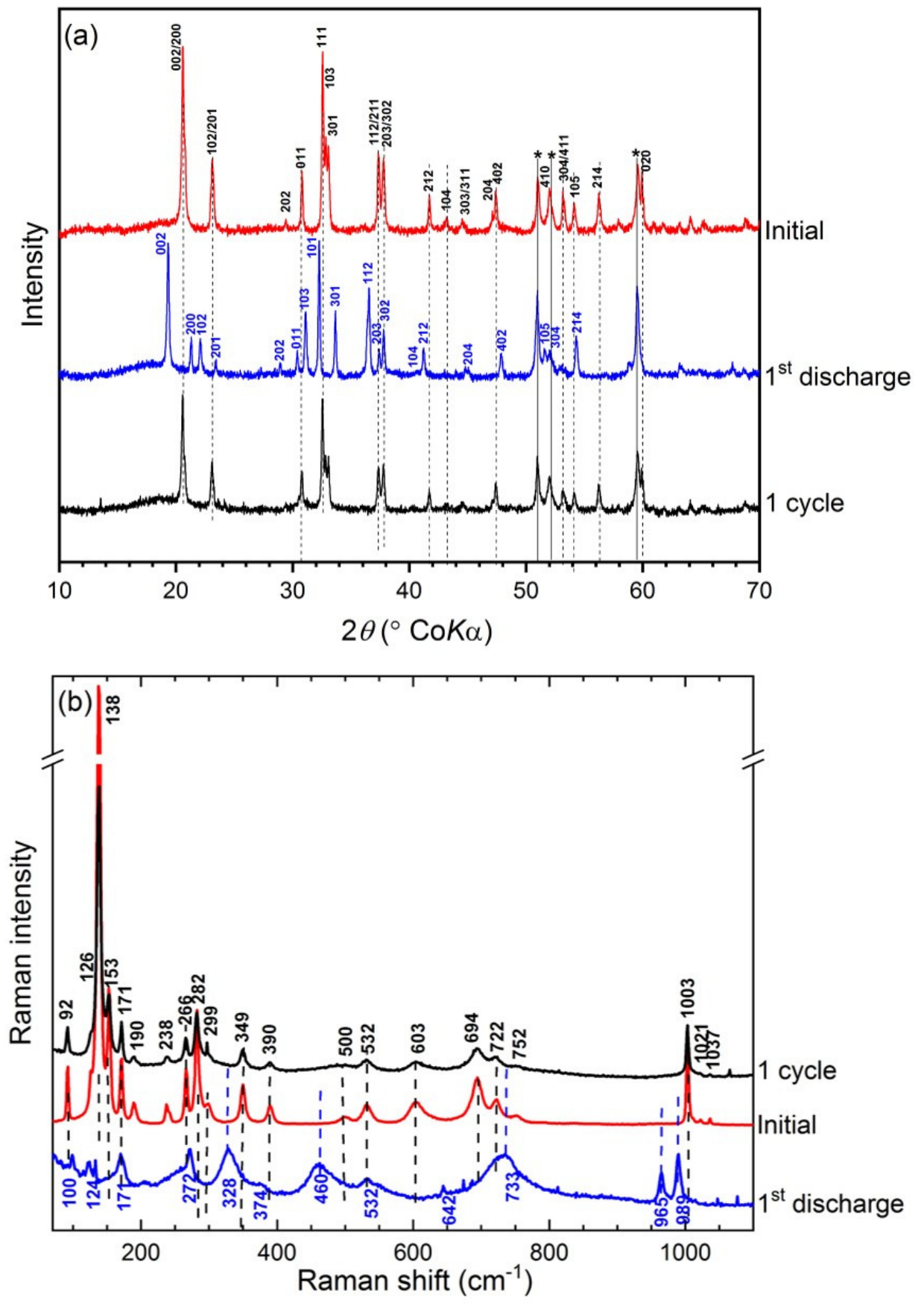

Fig. S7. (a) XRD patterns and (b) Raman spectra of initial $\gamma^{\prime}-\mathrm{V}_{2} \mathrm{O}_{5}$ electrode, after the first discharge and after the first discharge-charge cycle. *: sample holder (stainless steel) reflections. $1 \mathrm{C}$ rate. $1.6 \mathrm{~V}-0.7 \mathrm{~V}$ voltage window 

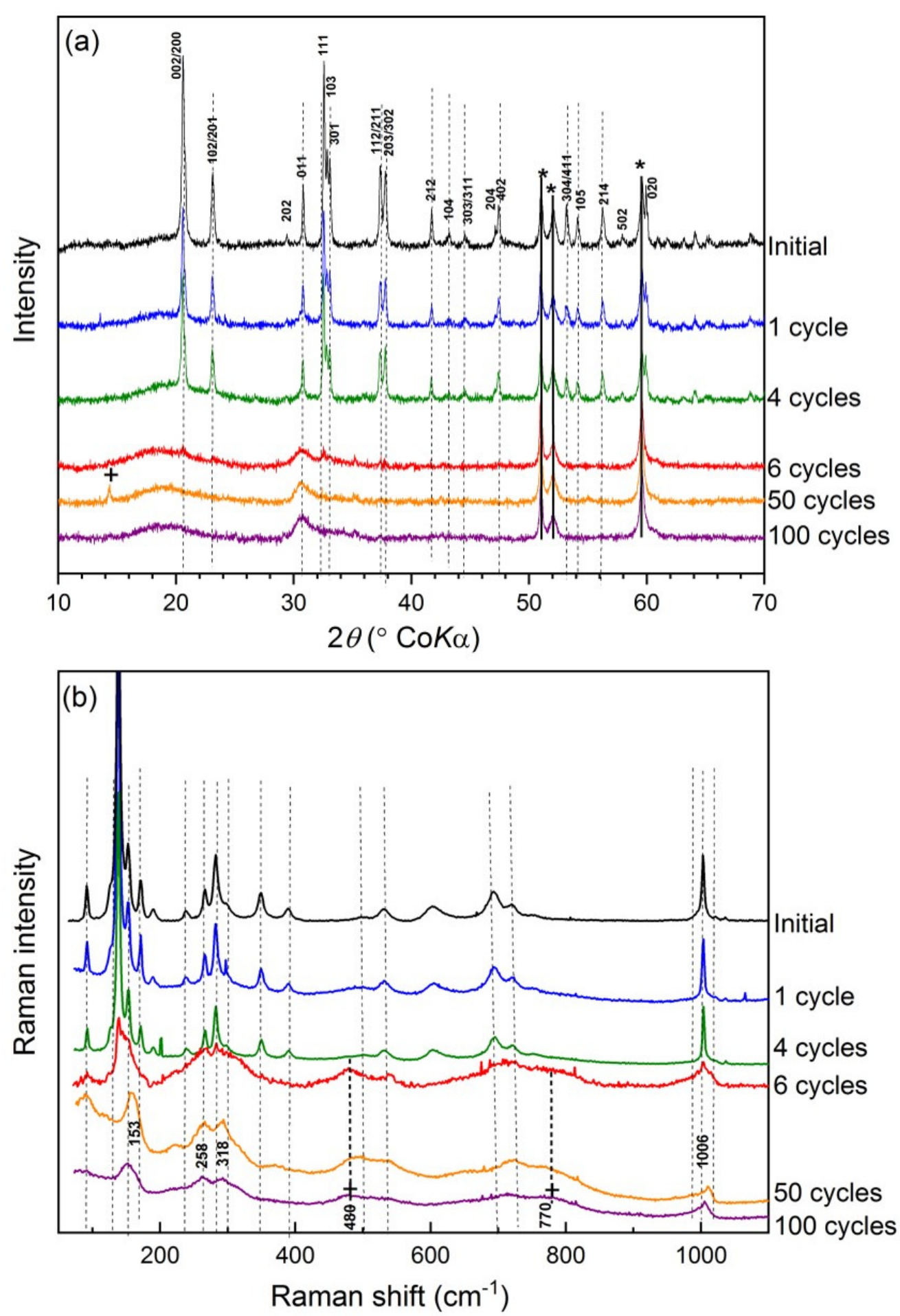

Fig. S8. (a) XRD patterns and (b) Raman spectra of initial $\gamma^{\prime}-\mathrm{V}_{2} \mathrm{O}_{5}$ and after cycle tests. *: sample holder (stainless steel) reflections. + : new phase. $1 \mathrm{C}$ rate. $1.6 \mathrm{~V}-0.7$ $\mathrm{V}$ voltage window 